Designing Public Open Space to Support Seismic Resilience:

A Systematic Review

by

\begin{abstract}
Emily L. French
A Thesis

presented to

The University of Guelph

In partial fulfilment of requirements

for the degree of

Master of Landscape Architecture
\end{abstract}

Guelph, Ontario, Canada

๑) Emily L. French, December, 2017 


\section{ABSTRACT \\ DESIGNING PUBLIC OPEN SPACE TO SUPPORT SEISMIC RESILIENCE: A SYSTEMATIC REVIEW}

Emily L. French

University of Guelph, 2017
Advisor:

Professor Karen Landman

In the wake of major earthquakes, public open spaces become hubs for both short-term disaster response efforts and support longer-term recovery needs. At present, few open spaces are actually designed to support these intermittent but critical uses. Currently, there is no consolidated body of knowledge or resource for landscape architects designing for areas of high seismic risk. This thesis identifies ways in which landscape architects can proactively plan and design open space to support seismic resilience. A systematic review of both grey literature and peer-reviewed academic papers was conducted. The results of the systematic review identified ten key themes. These themes contribute to developing a foundation for landscape architecture and allied design disciplines to better incorporate seismic resilience into the planning and design of public open spaces.

Keywords: earthquakes, disaster prevention parks, disaster resilience, landscape architecture 


\section{DEDICATION}

To Jeff, there is no one I would rather live in an active earthquake zone with

To my parents, Peter and Lesley, for your superhuman love and support

To my sister Norelle, my opposite side of the same coin

\section{ACKNOWLEDGMENTS}

Thank you to Professor Karen Landman for stepping in as supervisor and enduring the challenges of long distance co-ordination. To Professor Robert Brown for your continued involvement in my thesis even after a relocation to Texas. And, thank you to the Landscape Architecture Canada Foundation for financial support of this research. 


\section{TABLE OF CONTENTS}

ABSTRACT ___ ii

DEDICATION ___ _ _ iii

ACKNOWLEDGMENTS ___

LIST OF TABLES ___

LIST OF FIGURES______ vi

CHAPTER 1 | INTRODUCTION___ 1

1.1 | Growing Global Vulnerability ___ 2

1.2 | Frequency and Prediction___ 3

1.3 | Emergency Management____ 4

1.4 | The Built Environment and Open Space ___ 7

1.5 | Open Space and Disaster Resilience ___ 8

1.6 | Landscape Architecture and Disaster Resilience ___ 9

$1.7 \mid$ Research Goal ___ 10

CHAPTER 2 | LITERATURE REVIEW ___ 11

2.1 | Use of Open Space in the Post-Disaster Environment____ 11

2.2 | Landscapes in Transition ___ 15

2.3 | The Evolution of Open Space Design in Response to Disaster___ 18

2.4 | The Disaster Prevention Parks of Japan __ 21

2.5 | China and The Disaster Prevention Park Model __ 24

2.6 | Mitigation in the Absence of Past Disaster __ 26

CHAPTER 3 | METHODS ____ 28

3.1 | Search Strategy _ 28

3.2 | Study Selection__ 29

3.3 | Final Article Selection__ 30

CHAPTER 4 | RESULTS ___ _ 33

4.1| Multifunctionality and Embeddedness __ 33

$4.2 \mid$ Resilience __ 34

4.3 | Networks \& Connectivity___ 35

4.4 | Distribution \& Grouping __ 36

4.5 | Site Location \& Suitability___ 37 
4.6 | Size \& Function

4.7| Site Elements

4.7.1| Water 40

4.7.2 Sanitation 41

4.7.3 | Food 41

4.7.4 | Power \& Lighting 42

4.7.5 | Wayfinding \& Communication 42

4.8| Programming 43

4.9 | Community Engagement 44

4.10 | Education 45

CHAPTER 5 | DISCUSSION 46

CHAPTER 6 | CONCLUSION 54

6.1 | Limitations 54

6.2 | Future Research Directions 55

6.3 | Concluding Remarks 56

REFERENCES 57

APPENDIX A | Induced Seismicity 76

APPENDIX B | Prediction \& Early Warning 77

APPENDIX C | Secondary Disasters 78

APPENDIX D | Building Codes \& Compliance 79 APPENDIX E | Disaster Prevention Park Synonyms 81 


\section{LIST OF TABLES}

Table 1: Search Terms _ 29

Table 2: Final Article Summary ___ 31

Table 3: Disaster Prevention Park Size, Type and Function ___ 39

Table 4: Systematic Review Key Themes___ 46

\section{LIST OF FIGURES}

Figure 1: Emergency Management Cycle___ 4

Figure 2: Earthquake Park, Anchorage, Alaska __ 8

Figure 3: Christchurch pre- and post-earthquake ___ 16

Figure 4: Systematic Review Study Selection___ 30

Figure 5: Seseragi Stream - Matsumoto district____ 41

Figure 6: PREPHub Version $1.5 \ldots 43$ 


\section{CHAPTER 1 | INTRODUCTION}

Approximately 3 billion people currently reside in areas with high seismic activity, and in the last two decades an estimated 750,000 have died in earthquakes and subsequent tsunamis (UNISDR, 2016). By 2050, it is estimated that populations in major cities at risk from earthquakes will double (World Bank \& United Nations, 2010).

In the aftermath of a major natural disaster, open spaces such as parks, plazas, sports fields and streets have high occupation rates (e.g., Allan et al., 2013); "displaced residents will spontaneously converge on public parks and open space" (American Red Cross, 2011b, p. 7). Immediate needs such as evacuation, medical assistance, communication, shelter and distribution of food and water are often addressed in a city's open space (Masuda, 2014; Villagra et al., 2014; Allan et al., 2013). Public open space has been referred to as "vital" (Pizzo et al., 2014, p. 7) in the aftermath of an earthquake. Conversely, lack of large open space in the urban environment has been attributed to an increase in injury and death following an earthquake (Ainuddin \& Routray, 2012).

After the 2010 earthquake that devastated Haiti, there were reports of "hundreds of thousands of homeless people sleeping on the streets" (Steinman et al., 2012, p. 387). Immediately following the 2015 Gorkha earthquake in Kathmandu, Nepal, all of the city's 83 open spaces designated for use after disaster were occupied (Shrestha, n.d.). Five days later, 33 of these spaces were still in use, accommodating close to 40,000 displaced residents (Shrestha, n.d.). Fear of aftershocks can also drive people to shelter in parks and open spaces. In many cases, even after houses and buildings are deemed safe to return to, this fear can prevent people sheltering outdoors from returning home (American Red Cross, 2011a; Allan et al., 2013).

During the first few days after a natural disaster, before major relief efforts can be coordinated, residents are forced to improvise and search out open spaces that meet their needs for shelter and safety (Allan et al., 2013). Open spaces are seen with a new lens and "....are re-assessed for their capacity to support survival and recovery" (Allan and Bryant, 2010, p. 35). During this stage, life functions in large part in the open spaces of the city, and an alternative city or second city begins to evolve (e.g., Allan \& Bryant, 2011, 2014; Allan et al., 2013). 
Although some residents may be able to leave the affected area, and stay elsewhere, many others will be dependent on emergency aid and shelter offered at local facilities such as schools, churches and community centres. However, if the capacity of traditional emergency shelters is exceeded, or the earthquake has damaged the structure, local governments, nongovernmental organizations or displaced residents may establish Open Space Non Traditional Shelters (American Red Cross, 2011a).

Once the response and short-term recovery phase of the disaster is over, the community moves into long-term recovery. Many open spaces are officially designated by government agencies for recovery after disaster, such as the conscription of parks by the U.S. Federal Emergency Management Agency (FEMA) for temporary housing after Hurricane Katrina in New Orleans in 2005 (Rung, Broyles, Mowen, Gustat, \& Sothern, 2011). What's more, although open spaces may no longer be required to meet basic survival needs, they continue to play an important role in the psychological recovery of residents. This in turn provides a setting that fosters community ties and social interaction, further aiding in recovery (Rung et al., 2011; Villagra-Islas \& Alves, 2016).

Despite the importance of open space during the aftermath of disaster, current disaster mitigation efforts are heavily weighted towards building and infrastructure improvements (Allan et al., 2013). During this century of rapid urbanization, the need to retain and fortify open space is critical for urban disaster resilience. There is an opportunity to plan and design open space not simply to be a passive actor following seismic events, but also an active component in supporting response, recovery and resilience.

\section{1 | Growing Global Vulnerability}

An earthquake in isolation is termed a hazard, an inevitable natural occurrence. In an area that is prone to seismic hazards, yet has no population or infrastructure exposed, there is no risk. There are many cases of large magnitude earthquakes striking unpopulated areas without consequence. However, the same event occurring in a densely-populated city has a high risk of disaster.

As populations continue to develop in areas that act as natural hazard buffers, such as coastlines, wetlands and river deltas, or in areas along fault lines, disaster risk increases (Shannon, 2015). Often it is the most socially-vulnerable populations, who are least equipped to 
deal with hazards and their aftermath, who live in these hazards prone areas. Steiner (2014) describes this as a type of "ecosystem disservice" (p. 307). Income, age, race and education are all demographic characteristics that predict social vulnerability and can impact ability to cope with and recover from disaster (e.g., Cutter, Boruff, \& Shirley, 2003; Frigerio et al., 2016).

Poor construction techniques, inadequate building codes, centralization of infrastructure and dependence on technology also create a society that is physically vulnerable. As human populations grow in size and concentration, becoming more reliant on the features of the city, risk also grows (Flüchter, 2003; Godschalk, 2003; Wenzel, Bendimerad, \& Sinha, 2007). A seismic event can cause cascading failure of infrastructure, intensifying the disaster (Turer Baskaya, 2015).

Earthquakes can no longer be termed a "natural disaster" when they impact cities and their citizens. To do so implies that there is little that can be done to prevent ensuing disaster. Natural disasters are in fact human-made (e.g., Geis, 2000; UNISDR, 2015) and human settlements do not have to suffer from high levels of risk. Decreasing disaster risk involves our ability to reduce vulnerability and exposure to hazards. This can be achieved through resilient planning, design and construction of our cities (Geis, 2000; Godschalk, 2003).

\section{2 | Frequency and Prediction}

Just as potential for disaster following a natural hazard is human-made, earthquake hazards are quickly ceasing to be a solely natural phenomenon. Human-induced climate change, oil and gas industry operations (such as hydraulic fracturing) and ground water depletion (to name a few) are changing earthquake occurrence in a process called induced seismicity (see Appendix A).

In addition to the unpredictability of induced seismicity, earthquake prediction is currently marred by lack of collaboration and standardization in recording, processing, and reporting seismic events (Stefánsson, 2011). To date, accurately predicting seismic events "remains impossible" (Hunter, 2016, p. 416). Though earthquake prediction is still a developing field, progress is being made in the area of early warning (see Appendix B). Operational early warning systems are in place in Japan and Mexico, with smaller systems and functioning prototypes in China, Romania, Turkey, Taiwan and the U.S. (Strauss \& Allen, 2016; USGS, n.d.-a). However, until increased collaboration and standardization allows for more reliable 
prediction, and early warning systems are operational around the globe, we are left with unpredictability.

\section{3 | Emergency Management}

Planning for and responding to this unpredictability is the role of emergency management. The cycle of emergency management is commonly broken into four interconnected phases (punctuated by the event): preparedness, response, recovery and mitigation (e.g., Government of Canada, 2016a). Because of their rapid onset and lack of lead-time, earthquakes pose particular difficulty, and actions taken in advance of an earthquake are critical.

\section{Preparedness}

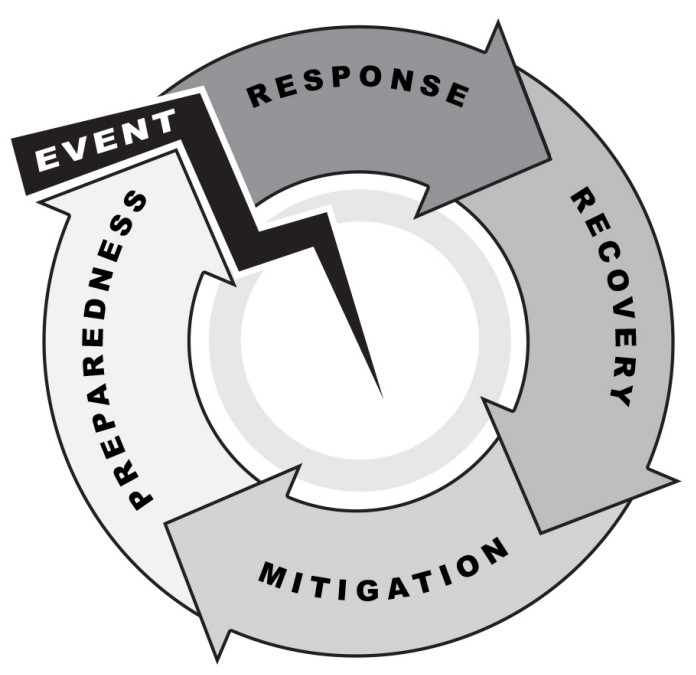

Figure 1: Emergency Management Cycle (Source: Author)

The preparedness phase includes planning and activities that ensure effective response and recovery after a disaster (UNISDR, 2017). A key factor in protection against the impacts of an earthquake is local-level community preparedness (Smith, 2013). In Japan, residents are told to plan for a minimum of one week without outside assistance (Tokyo Metropolitan Government, n.d.). In many other countries, including Canada and the United States, local, provincial/state and federal governments advocate for only 72 hours of self reliance (e.g., Department of Homeland Security, 2007; Public Safety Canada, 2012).

During this period, residents are advised to prepare for coping without life lines, such as electricity, telephones or running water (Department of Homeland Security, 2007). Factors such as previous disaster experience, number of dependents and trust in government all affect preparedness, while different community and individual needs and vulnerabilities add further complexity (Kohn et al., 2012). Despite actions to raise awareness, such as public education campaigns, disaster preparedness levels continue to be low. Individuals and households tend to overestimate their preparedness, leading to further dependence on emergency services (Paton, 2003). 


\section{The Event}

Earthquakes are violent, deafening and disorienting. People often report intense feelings of fear and helplessness, like the world is about to end (Lucini, 2014). Shaking can be so intense during an earthquake that you are unable to stand (Centers for Disease Control and Prevention, 2014). A person's experience of the shaking will depend on their location in relation to the earthquake epicenter, type of fault rupture and the way in which the seismic waves move through the ground (Michael, n.d.). Typically, the larger the magnitude of the earthquake, the longer the duration of shaking (Michael, n.d.). Shaking can last anywhere from a few seconds to a few minutes (USGS, n.d.-b).

Once the shaking stops, residents are instructed to "go to an open space away from damaged areas" (Department of Homeland Security, n.d.). It is common to hear news reports of people flooding into streets and public open space in search of safety (e.g., AFP news agency, 2017; Al Jazeera News, 2016; Jones \& Agren, 2017).

Although the earthquake alone can cause massive destruction, the secondary hazards that follow as a result of the shaking can be equally dangerous (Daniell, Schaefer, \& Wenzel, 2017; Journeay et al., 2015). Depending on your location, a range of secondary hazards can be triggered, including liquefaction, landslides, flooding, fires and tsunamis (see Appendix C). Daniell et al. (2017) found that secondary effects cause $29 \%$ of fatalities during earthquakes.

The first 72 hours after a disaster has been referred to as a "vacuum of authority" (Halford \& Nolan, 2002 in Lowe \& Fothergill, 2003, p. 293) when residents are largely on their own, before formal rescue and relief teams have been mobilized or can access affected communities. During this period, social networks play an important role supporting those in need. In many cases it is neighbours who are first on the scene. Following the 2002 Molise earthquake in Italy, survivors described spending the first night in the middle of the street together with friends, family and neighbours, who were the soul source of support and aid (Lucini, 2014). In Iran, survivors of the 2003 Bam earthquake are estimated to be responsible for the rescues of over 2000 people from the rubble in the hours following the earthquake (Smith, 2013).

\section{Response}

Immediate disaster response is the domain of local government, focused on addressing urgent needs, such as evacuation, first aid, search and rescue, and security (Alexander, 2002; World 
Bank \& United Nations, 2010). First responders (emergency medical professionals, local police and fire fighters) are key to the success of the response stage (Haddow, Bullock, \& Coppola, 2014).

The response phase also deals with provision of emergency shelter (typically overnight stays) and temporary shelter (several days) (Quarantelli, 1995). Once immediate response needs are addressed, priorities such as re-establishing supply chains and setting the groundwork for longterm recovery become the focus (EMBC \& B.C. Ministry of Justice, 2015).

\section{Recovery}

The transition from response to recovery is often not clearly defined, and actions associated with the response phase frequently overlap with recovery (World Bank \& United Nations, 2010). Recovery has been described as a "post-disaster scramble" (Vallance, 2011, p. 23) which is "marked by conflict and disillusionment" (Edgington, 2010, p. 105). Continuing aftershocks and secondary disasters can also slow recovery, or cause a city to fall back into the response phase.

Recovery includes activities that restore, rebuild and reduce risk of future disaster (UNISDR, 2017). Though the recovery period may be viewed as an opportunity for change or chance to 'build back better' (e.g., World Bank \& United Nations, 2010), time constraints and pressure to rebuild and return to normal as quickly as possible often preclude taking actions to reduce future disaster risk (Allan \& Bryant, 2014; Kim \& Olshansky, 2014). During recovery there is the danger of building back the same vulnerabilities.

\section{Mitigation}

Mitigation describes actions taken to reduce the severity of a hazard and involves a wide range of expertise, from planning and policy to education and engineering (UNISDR, 2017; World Bank \& United Nations, 2010). The adoption and implementation of seismic building codes and engineered solutions are the most common forms of mitigation (see Appendix D). Yet, despite technological advances in seismic design of structures, the number of fatalities annually continues to climb (Ambraseys \& Bilham, 2011). 


\section{4 | The Built Environment and Open Space}

Given the immense toll that building collapse can take on human life, it is perhaps unsurprising that current earthquake mitigation is largely focused on engineering structures and infrastructure in the built environment. However, there is a tendency to overlook open space as a component of the built environment. Although the built environment includes many different practices relating to "the design, development and management of buildings, spaces and places" (Griffiths, 2004, p. 711), open space is frequently treated as somehow separate. Amaratunga \& Haigh (2011) note that when the term 'built environment' was first introduced in the 1980s, it was used to describe ways humans interact, modify and produce their environment, and also included the landscape and urbanism, not simply architecture and building engineering.

Allan and Bryant (2011) give the example of a document from the New Zealand Ministry of Civil Defense and Emergency Management that considered the built environment as a collection of buildings and infrastructure. Open space, the underpinning matrix of these two elements, was treated as separate, and "addressed in a section on the natural environment where the focus is on the recovery of these environments rather than their capacity to support recovery"(Allan \& Bryant, 2011, p. 34).

Despite this separation, open space plays an important role in mitigation. Geis (2000) lists "design and patterns of open space" (p. 157) as core areas to consider in disaster mitigation. Changes to land use, zoning and prohibiting construction near faults are common planning techniques used to buffer or prevent future development in hazardous areas (Bahrainy, 1998; Olshansky, 2001). Frequently, municipalities acquire land that has either been damaged during disaster or identified as high risk to natural hazards, and convert the land to park space for passive recreation (Ibes, 2008).

The landslide that followed the 1964 earthquake in Anchorage, Alaska, caused a portion of the bluffs in the Cook Inlet to subside by over 10 meters, breaking the land into large blocks and creating steep ridges (Thoms, Haeussler, Anderson, \& McGimsey, 2014). Because of the area's instability, re-development was kept to a minimum and a large segment was converted into parkland. Today, Anchorage's 'Earthquake Park' (see Figure 2), "is the [city's] only reminder of the earthquake's devastation" (Municipality of Anchorage, n.d.). 

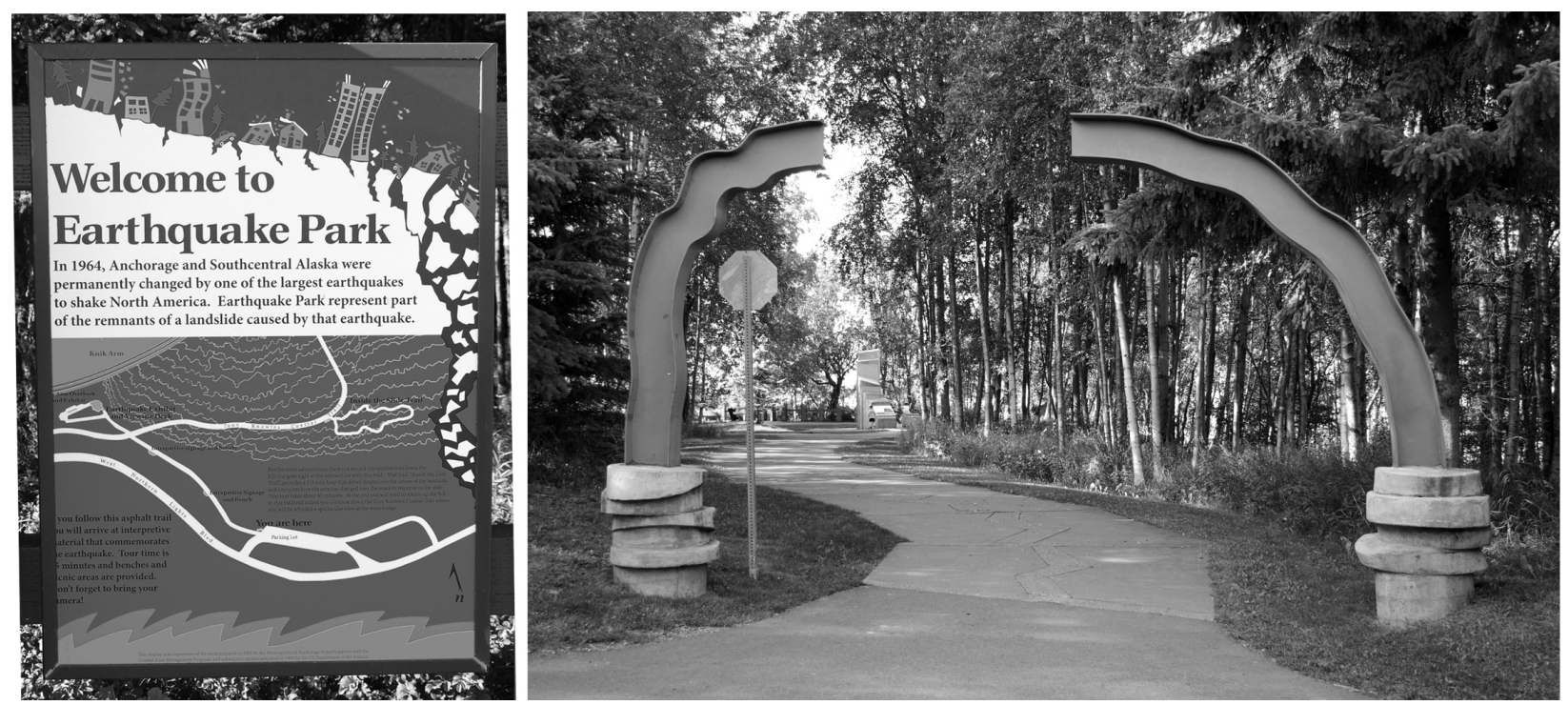

Figure 2: Earthquake Park, Anchorage, Alaska (Source: Author)

\section{5 | Open Space and Disaster Resilience}

While both land use rezoning and restriction of construction in hazard prone areas are effective, there is growing interest in using open space not simply as a barrier, but as an active component in supporting disaster resilience. Depending on the discipline in which it is used, the term resilience can have a number of definitions. In the context of disaster, it refers to a community's ability to "resist, absorb, accommodate, adapt to, transform and recover from the effects of a hazard in a timely and efficient manner" (UNISDR, 2009). The specific ability of a community to mitigate hazards, limit the extent of damage from disaster, reduce social disruption during recovery and lessen impacts from future earthquakes defines a community's seismic resilience (Bruneau et al., 2003).

Literature shows that improvements to public open space can have positive effects on disaster resilience (e.g., Bahrainy, 1998; Tumini, Villagra-Islas, \& Herrmann-Lunecke, 2017). Yet, resilience theory has limited advice for design, focusing instead on "policy and management" (Childers et al., 2015, p. 3779). There is still limited information about how to design for resilience (Allan et al., 2013), and even less information on designing public open space to support disaster resilience (Jayakody, Amarathunga, \& Haigh, 2016). There is also little information on the specific characteristics or qualitative aspects that is required for public open space to effectively respond to seismic risk (Allan \& Bryant, 2010; Pizzo et al., 2014). 
With the surge of interest in resilient design and resilient cities, professional bodies are addressing these issues more pointedly. The American Society of Landscape Architects launched a website in September 2016 dedicated to educating practitioners and showcasing projects that address resilience. The site profiles design for flooding, drought, landslides, extreme heat, fire and loss of biodiversity. Although flooding, landslides and fire can follow earthquakes; there is nothing that deals directly with earthquakes and building collapse, or other secondary hazards such as tsunamis and liquefaction.

A limited but growing body of literature is beginning to address the use of open space in the post-disaster context (e.g., Allan \& Bryant, 2011; Montejano-Castillo \& Moreno-Villanueva, 2016; Villagra-Islas \& Alves, 2016; Wesener, 2015). Most of the papers specifically state that findings are intended to be used as a guide for urban designers and allied professions such as landscape architects working in urban areas prone to earthquakes (Allan \& Bryant, 2011; Allan et al., 2013; Villagra, Rojas, Ohno, Xue, \& Gómez, 2014). However, this and other literature that could contribute to designing public open space to support seismic resilience has not been consolidated.

\section{6 | Landscape Architecture and Disaster Resilience}

Design disciplines are "key contributors to disaster resilience" (Mazereeuw \& Yarina, 2017, p. 65). Bahrainy (1998) states that one of the primary objectives of planning and design disciplines should be to increase the safety of communities from the effects of earthquakes. Yet, "...spatial planners, urban designers and landscape architects are rarely involved" (Allan \& Bryant, 2010, p. 34).

Landscape architects are featuring more prominently in the disaster recovery phase - for example, the employment of landscape architects by New York City Department of Parks \& Recreation - Storm Response Unit, to document park system damage following Hurricane Sandy in 2012 (Mclntyre, 2013). While involvement during this phase is important, literature demonstrates that interventions taken prior to disasters are critical (Allan et al., 2013; Turer Baskaya, 2015).

Landscape architects are trained to consider changing systems, and to plan and design for temporal and spatial changes in the environment - all key factors in addressing risk (Mazereeuw, 2015). The discipline has both the ability and responsibility to increase urban 
resilience through planning and design for disaster mitigation (Copley, Bowring, \& Abbott, 2015; Turer Baskaya, 2012). However, there is a need for more clarity around both the role of public open space after an earthquake, and how to design open spaces to support response and recovery in the post-disaster landscape (Allan \& Bryant, 2010).

\section{7 | Research Goal}

The goal of this research is to explore the literature to learn how landscape architects can proactively plan and design public open space to support seismic resilience.

\section{Objectives:}

1. To locate and consolidate existing research on planning and design for seismic resilience from the discipline of landscape architecture and related professions

2. To identify major themes that appear in the aggregated research

3. To provide a foundation for the development of guidelines for landscape architects and related professions to better incorporate seismic resilience into the planning and design of public open spaces. 


\section{CHAPTER 2 | LITERATURE REVIEW}

This literature review is divided into six primary sections. The first two sections address perception, selection and use of open space by communities in the post-disaster environment. Temporary community initiatives that transform vacant urban spaces in the aftermath of disaster are also included. Sections three and four follow the evolution of open space in response to disasters in Japan, with examples of both top-down government-led and bottom-up communityled initiatives. The final two sections address the design of open space for disaster mitigation, using China as an example, and note some of the challenges of mitigation in the absence of past disaster experiences.

\subsection{Use of Open Space in the Post-Disaster Environment}

Current literature on the topic of open space in the post-disaster environment generally focuses on five main earthquake events that occurred in San Francisco, Concepción, Mexico City, Tokyo, and Christchurch. The Great San Francisco earthquake and the ensuing fires of 1906 destroyed more than 500 blocks in the City's downtown core and left over half of San Francisco's 400,000 residents homeless. Although many chose to leave the ravaged area, an estimated 250,000 stayed in San Francisco. Parks became locations for informal camps. Eventually 26 official refugee camps were established by the City (National Park Service, n.d.1, n.d.2). Local parks, hilltop parks, and city streets played a key role in San Francisco's disaster response and recovery (Allan \& Bryant, 2011).

Villagra, Rojas, Ohno, Xue, \& Gómez (2014) collected information from those involved in emergency response after the 2010 Chilean earthquake and identified the type, distribution and use of open spaces that were important in recovery. Of the seven types of open space described, free areas (e.g., sports fields and parking lots), green areas (e.g., parks and plazas) and street networks were the most heavily used.

Similarly, in their study of the adaptability of public space after the 1985 earthquake in Mexico City, Montejano-Castillo \& Moreno-Villanueva (2016) identified eight types of open space that were used after the disaster: streets, avenues, railways, esplanades, squares, roundabouts, sports fields and transit stations. The study found that public squares provided the "most potential for refuge and post-disaster organization" (p. 111). Open space on a smaller scale has 
also been shown to play a role in recovery. In Concepción, Chile, residents' front yards became a place to interact and strategize with neighbours, while people were able to retreat to their backyards to sleep or for privacy (Allan et al., 2013).

\section{Site Selection}

The selection criteria used to identify open spaces for use in the aftermath of disaster vary. Perhaps one of the most obvious, but critical drivers is the type of secondary disaster faced in an area. In the event of a tsunami, for example, open spaces that are elevated, set back from the coast, and can support a large number of evacuees are typically sought out (Allan et al., 2013). After the 1923 Great Kanto Earthquake in Japan, fires devastated the City of Tokyo. Approximately 1.57 million residents sought shelter in parks that were surrounded by vegetation, which acted as a buffer from the fires (Masuda, 2014).

Aspects of shape, size, accessibility and connection to infrastructure (e.g., water, power, sanitation) are also key considerations (Allan et al., 2013; Montejano-Castillo \& MorenoVillanueva, 2016). Allan et al. (2013) also note that a site's historic use in previous disasters was also a predictor of selection.

Proximity to one's home and neighbourhood was perhaps the most frequently cited reason for site selection (e.g., Allan \& Bryant, 2011; Allan et al., 2013; Montejano-Castillo \& MorenoVillanueva, 2016; Villagra et al., 2014). Despite official shelters made available to the public, many residents choose to stay close to home, even if it had been destroyed in the earthquake. According to Montejano-Castillo \& Moreno-Villanueva (2016) both fear of looting and a sense of rootedness to ones' home was cited as a reason for choosing to remain.

\section{Function and Use of Open Space}

In San Francisco, the immediate needs of the population that remained in the city after the earthquake were for "security and shelter" (Allan \& Bryant, 2011, p. 35). As noted in the introduction, local parks became hubs of social support for the community and provided opportunities for exchange of information.

The local streets of San Francisco also functioned as outdoor kitchens, providing areas for families to prepare food over campfires. Makeshift "street kitchens" (Allan \& Bryant, 2011, p. 35) 
were also assembled from scrap and salvaged stoves. Wider commercial streets in the city functioned as evacuation routes immediately after the earthquake, and once the city began to recover, these main streets housed improvised storefronts allowing commerce to resume (Allan \& Bryant, 2011).

In Mexico City, street networks were also important for temporary camps and co-ordination of relief efforts. Public squares functioned in a similar capacity, but also acted as a base for medical aid, supply distribution, communication and food preparation (Montejano-Castillo \& Moreno-Villanueva, 2016). In Christchurch, New Zealand, the city's parks also played a critical role, providing shelter immediately following the earthquake and a place to co-ordinate search and rescue operations (Brand \& Nicholson, 2016). Later, mobile shower and washroom facilities, as well as water distribution stations were set up in city parks (Galloway et al., 2014).

\section{Landscape Attributes \& Perception}

The use of open space after a disaster is also dictated by perception. An extensive body of literature addresses landscape and perception from a number of viewpoints and disciplines (e.g., Gobster, Nassauer, Daniel, \& Fry, 2007; Kaplan, Kaplan, \& Brown, 1989). Gobster et al. (2007) note that our specific needs, and the situations we find ourselves in, change our perceptions of the landscape.

This is particularly true in the post-disaster environment, when perceptions of open space shifts to supporting survival (Allan \& Bryant, 2011; Allan et al., 2013; Villagra-Islas \& Alves, 2016; Villagra-Islas \& Dobbie, 2014). Villagra-Islas and Dobbie (2014) focused on perceptions of urban wetlands in Concepción, Chile, after the 2010 earthquake. During normal times, aesthetic aspects of wetlands and their affordances, such as recreation and observing nature were preferred. Post disaster, perception of affordances shifted based on the population's need for water. Although wetlands and other "wet landscapes" (p. 678) satisfied this need, they were only seen as being useful for short periods of time. Open spaces that were upland and dry were perceived as safer and more suitable for temporary camps.

Villagra-Islas and Alves (2016) considered a broader array of landscapes in Concepción. The authors identified three attributes that affect people's use of open space: built features, water and greenery. Although the attributes affected both non-emergency and emergency situations, their importance changed. During the non-emergency scenario, preferred attributes were natural 
features and urban facilities. Vegetation was identified as the key attribute during this scenario, seen as important for activities like picnicking and general recreation. During an emergency, the degree of urbanization and presence or absence of water was prioritized, with water identified as the key attribute.

\section{Open Space \& Recovery}

While there are attributes that are important during the emergency response and short term recovery phases after an earthquake, literature that addresses the use of open space and longterm recovery is scarce and tends to bleed into other disciplines, as the lines between the recovery phase and a return to normal daily activity become less defined.

While buildings and infrastructure dominate the discourse on recovery, attention must also be given to the psychological damage left by disaster. Services that address issues of mental health and promote personal safety are critical for psychosocial recovery. Survivors of disaster often face injury or death of family and friends and massive loss of personal property, community, and support systems (Madianos \& Evi, 2010). High rates of post-traumatic stress disorder and worsening of anxiety and depression are common after disaster (e.g., Kilic \& Ulusoy, 2003; Madianos \& Evi, 2010; Risler et al., 2015). Incidents of domestic violence also increase after disaster impacting ability to recover (e.g., First, First, \& Houston, 2017; Harville, Taylor, Tesfai, Xu Xiong, \& Buekens, 2011; Lauve-Moon \& Ferreira, 2017).

The connection between green space and its restorative and healing qualities is well established in non-disaster context (e.g., Marcus \& Sachs, 2014; Nutsford, Pearson, \& Kingham, 2013; Tyrväinen et al., 2014; van den Berg, Maas, Verheij, \& Groenewegen, 2010). However, the results of Villagra-Islas \& Alves (2016) study on the post-earthquake landscape in Concepción, Chile, showed that restorative qualities did not seem to play a significant role and were not associated with any kind of environmental use.

The Rung et al. (2011) study of park use and restoration in New Orleans after Hurricane Katrina (2005) found that residents from neighbourhoods that had been impacted by flooding, used parks less frequently than unaffected neighbourhoods. The authors speculate that residents from flooded neighbourhoods simply had less time to make use of parks, and were still dealing with additional responsibilities stemming from the flooding. 
Although people may not be seeking open or green space specifically for restoration, the programming in open space, such as community gardens, has been shown to impact restoration and support recovery. Chan, DuBois, \& Tidball (2015) found that community gardens in New York City were important sources of neighbourhood support while recovering from the effects of Hurricane Sandy in 2012.

\section{2 | Landscapes in Transition}

During the post-disaster recovery phase, cities are rapidly changing and evolving. Often, familiar landscapes have become hazardous due to unstable structures (both natural and built). Large voids exist where landmarks, streets, buildings and their associated functions and people used to be. The city has become unfamiliar even to life-long residents. Bowring \& Swaffield (2013) describe this state as a dislocation of "the basic functions of life" (p. 7) and a destabilizing of sense of place. Prewitt Diaz \& Dayal (2008) refer to this loss of place during a natural disaster as catastrophic.

In their essay on the shifting landscape in the aftermath of an earthquake, Bowring and Swaffield (2013) note that the discipline of landscape architecture addresses these "dynamic, transient, and to a significant degree, indeterminate" (p. 2) elements (such as seasonal changes, the movement of water, plant growth, and soil variability). However, landscape architecture also assumes a level of predictability in which this change is framed, allowing for time to consider specific site conditions (Bowring \& Swaffield, 2013).

Events like flooding, storms and drought are also accommodated for in design. However, when major disruption in the landscape occurs, this approach is no longer effective during this period. Aftershocks can continue for months, even years, after an initial earthquake, making reconstruction efforts and returning to a state of normalcy difficult (Bowring \& Swaffield, 2013). In Christchurch, New Zealand, thousands of aftershocks followed the 2010 and 2011 earthquakes, 250 of which had a magnitude of 4.0 or greater (Statistics New Zealand, 2011).

The use of design for this dynamic time of transition is still a largely unexplored area. Wesener (2015) notes that although there is a great deal of scholarship that deals with the planning and design of temporary housing and settlements during this transitional period, there is a gap in the literature on "temporary post-disaster urbanism in the form of (public) open space" (p. 407). 


\section{Transitional Community-Initiated Open Space in Christchurch, New Zealand}

In many cases where vacant land has been used or occupied by the community after a disturbance, issues arise with government planning initiatives and landowners (Brand \& Nicholson, 2016; Wesener, 2015). Wesener (2015) states that "discordant development vision or anticipated permanent uses" (p. 418) are examples where conflict can arise. However, in Christchurch, New Zealand, grassroots initiatives have flourished through agreements with landowners that permit the use of vacant space until redevelopment occurs (Montgomery et al., 2016). There is particular interest in community responses to these landscapes in transition in Christchurch, and a body of work has emerged on the temporary use of vacant spaces resulting from the 2010 and 2011 earthquakes (e.g., Bowring \& Swaffield, 2013; Brand \& Nicholson, 2016; Wesener, 2015).

The eastern suburbs and the central business district of Christchurch were two of the hardest-hit areas, requiring the demolition of close to $90 \%$ of the buildings (Dionisio, Kingham, Banwell, \& Neville, 2016). Not only were there spatial voids, there were also large voids in the population. Following the earthquakes, 9000 residents left the city, the largest movement of people in New Zealand's history, to date (Dionisio et al., 2016). This exodus required the remaining population to reshape both the environmental and social fabric of the city.
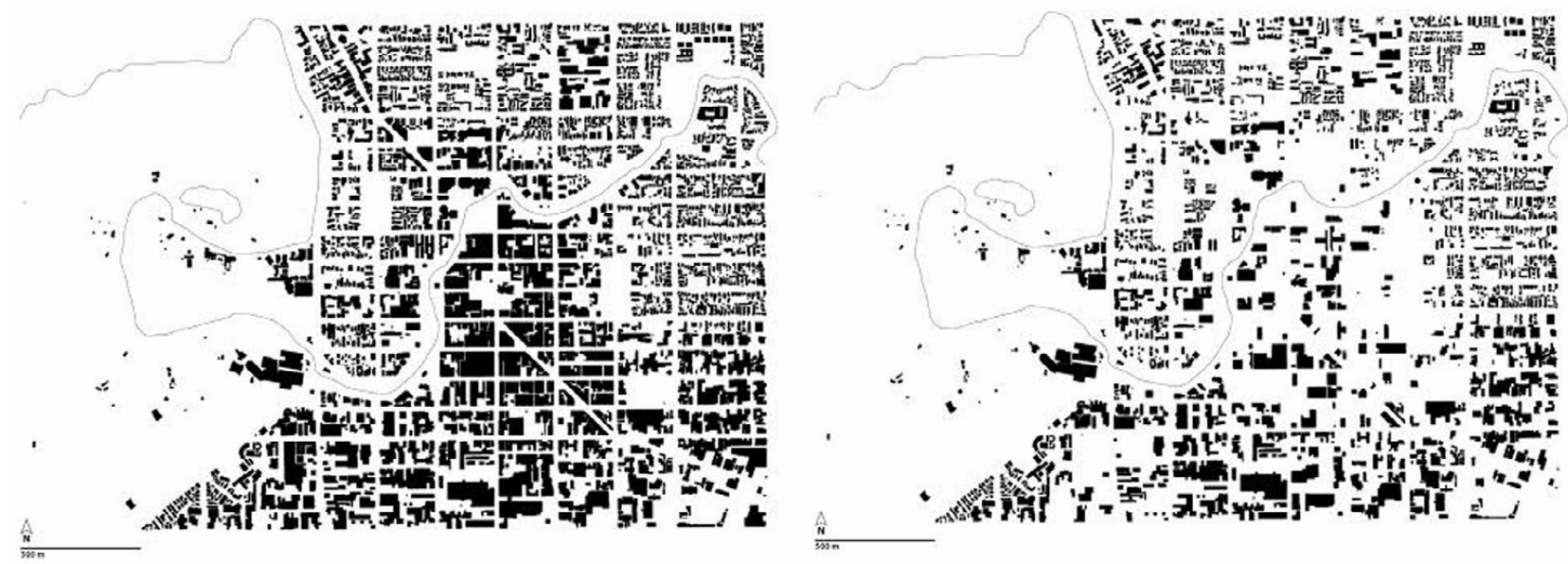

Figure 3: Christchurch pre- and post-earthquake (Brand \& Nicholson, 2016, p. 162)

Almost immediately after the 2010 earthquake, community organizations began to form to address the excess of vacant urban spaces. Community-driven projects operated "parallel to the 'official' rebuild discourse" (Wesener, 2015, p. 406). While government reconstruction planning proceeded, innovative transient projects gave residents a way to revive life in Christchurch (Bowring \& Swaffield, 2013). 
Wesner (2015) and Montgomery et al. (2017) refer to these initiatives as transitional communityinitiated open space (CIOS). Unlike large-scale government-led reconstruction, CIOS projects have the freedom to experiment and innovate. Without the constraint of having to produce permanent spaces or structures, the community is able to respond and adapt quickly to the changing landscape (Gap Filler, n.d.).

The two most prominent CIOS organizations that developed in the aftermath of the 2010 earthquake were 'Gap Filler' and 'Greening the Rubble' (Montgomery, 2012; Wesener, 2015). Both developed "temporary projects using vacant earthquake sites as activity spaces" (Wesener, 2015, p. 411). Gap Filler describes their organization as a "creative urban regeneration initiative" (n.d.). To date, the group has facilitated 75 temporary installations and events in the City, from pavilions made of wooden pallets and pétanque courts, to traveling popup dance floors and outdoor movie theaters (Gap Filler, n.d.). Of the two organizations, Greening the Rubble deals most directly with the landscape, creating temporary parks and gardens on vacant sites in the City (Greening the Rubble, n.d.-b; Wesener, 2015). The organization has worked with landscape architects, artists the Department of Conservation and school groups (to name a few) in the development of these spaces.

Wesener (2015) found that CIOS organizations contribute to community resilience, and lists a number of benefits, including increasing social capital, fostering positive experiences and emotions and "encouraging experimentation and innovation" (p. 418). This is echoed by Brand and Nicholson (2016) who note that urban space projects in Christchurch became "a mechanism and a symbol of community resilience" (p.174) and acted as "a discernible barometer of collective recovery"(p.174), restoring a sense of balance and control to the lives of those who chose to remain in the City.

Despite the importance of these temporary projects in the recovery process of a community, it is difficult for conventional urban planning to predict their occurrence (Wesener, 2015). However, Brand and Nicholson (2016) suggest that the urban structure of the City might have contributed to their development by providing a level of flexibility during the recovery phase that “...facilitated rapid rebound" (p.174). Although these CIOS initiatives were originally intended to be temporary, Montgomery et al. (2016) found that some of the projects have become semipermanent. An ad-hoc pocket park attached to a coffee kiosk, aptly named 'Coffee Zone', was 
constructed by Greening the Rubble in 2011. The project is still in place today and continues to expand (Greening the Rubble, n.d.-a).

The Fitzgerald Ave. Community Garden, constructed in 2012, also remains, although as time passes those involved with its construction and maintenance have moved on and there has been a reduction in upkeep and use of the garden (Montgomery et al., 2016). Montgomery et al. (2016) ultimately question the importance of the product versus the process and speculate that what was most valuable for the community, at the time, was the planning and construction of the garden. To a certain extent the parks and gardens created by Greening the Rubble have served their purpose, leaving Montgomery et al. (2016) to question their current relevance to the community.

In every post-disaster landscape, communities evolve new ways of using and perceiving open space. The ability for residents to feel in control of their surroundings and remain connected to their neighbourhood is important in the recovery process. Although it is tempting to begin to draw universal conclusions from the literature, there is no one-size-fits-all solution (Amaratunga \& Haigh, 2011; Dobbie \& Green, 2013). The use of open space after a disaster is shaped by specific geomorphology and resulting urban form, historic use of open space, and the unique socio-cultural context of the area.

\subsection{The Evolution of Open Space Design in Response to Disaster}

Asia-Pacific, the world's most disaster-prone region, is particularly vulnerable to earthquakes (UN, 2016). From 2001-2011 earthquakes accounted for 68\% of disaster-related deaths in Asia and had the largest economic impact of any other type of disaster in the region (OCHA, 2012). Allan et al. (2013) state that a region which is repeatedly exposed to disaster "develops learned adaptive behaviours, further enhancing resilience" (p. 246). Moreover, disaster is said to uncover the root causes of risk, providing countries with critical insight and opportunities for change.

\section{Japan and Natural Disaster}

One of the most seismically-active countries on earth is Japan. With 2000 active faults running under the archipelago, Japan experiences $20 \%$ of the world's earthquakes measuring a magnitude 6.0 or greater (The University of Tokyo, n.d.). Japanese identity and cultural 
nationalism are intimately linked with natural disaster (Clancey, 2006). Both Clancey (2006) and Weisenfeld (2012) have called disaster a generative force in the culture of Japan, shaping everything from moral and spiritual practices, to politics, art and design. Today, Japan employs the most extensive early-warning system, network of seismometers and public education initiatives for earthquakes and tsunamis in the world (Cyranoski, 2011).

The evolution of Japan's open space in response to natural disaster is particularly prescient, with open spaces (specifically green space and parks) designed to support the response and recovery phases of future natural disasters. Although many of Japan's initiatives have failed to move past the planning stage, being thwarted by politics or economics, the insights provided by the various strategies considered over the last century and a half are valuable precedents.

\section{Industrialization and The Great Kanto Earthquake}

In 1868, a process of rapid industrialization began after a new party rose to power, replacing the last of the feudal military governments in Japan (Kumagai et al., 2015). Along with industrialization came the depletion of Japan's green spaces which were seen as "a luxury that may be given up to accommodate the perceived necessity of industrial development" (Kumagai et al., 2015, p. 1025). By 1922, parkland in Tokyo had been reduced to $1.7 \%$ of the city's land cover (Schencking, 2013).

In 1923, The Great Kanto Earthquake struck off the coast of Japan, followed by tsunamis and landslides in coastal regions (Flüchter, 2003). The magnitude 7.9 earthquake was the most "deadly, economically costly, and physically destructive" (Schencking, 2006, p. 833) natural disaster in Japan's prewar history. The number of deaths reported range from 80,000 (Kumagai et al., 2015) to over 140,000 (Flüchter, 2003). Much of the devastation experienced came from the secondary effects of fires that tore through Tokyo (Flüchter, 2003).

In contrast to the grid iron plan of many North American or European cities, Hein (2002) likens Japanese cities to "organic cells [that] form urban organisms" (p. 221). Ma and Ohno (2013) further elaborate that narrow winding streets surrounded by wood-framed houses typify many traditional Japanese neighbourhoods. These densely packed districts were highly susceptible to the fires, and $70 \%$ of the buildings in Tokyo (including 380,000 houses) were destroyed (Kumagai et al., 2015; Schencking, 2006). Tokyo's remaining green space played a critical role in post-disaster response and recovery, sheltering close to 1.6 million residents from the fires 
(Flüchter, 2003; Kumagai et al., 2015; Masuda, 2014). The City's parks and green spaces provided the "adaptive capacity to face sudden disaster" (Kumagai et al., 2015, p. 1025), cementing the "significance of urban green spaces as disaster refuge areas" (Masuda, 2014, p. 53).

In the wake of Tokyo's recovery from The Great Kanto Earthquake, the government developed "The Imperial Reconstruction Plan" (Park, Takeda, Kaga, \& Masuda, 2016, p. 205). It proposed the development of $3.3 \mathrm{~km}^{2}$ of new green space, (Kumagai et al., 2015), specifically the creation of "...three new large-scale parks and 52 new small scale parks within the City of Tokyo" (Masuda, 2014, p. 53). Although the amount of green space was reduced to just $0.4 \mathrm{~km}^{2}$ (Kumagai et al., 2015), the reconstruction plan demonstrated the growing understanding of the need for green space specifically constructed for disaster refuge (Masuda, 2014).

Ishikawa (2002) credits the post-disaster reconstruction of the City with providing the "fundamental structure of modern Tokyo"(p. 833). However, Havens (2011) points out that, despite the strides made after the earthquake, the rapid pace of recovery following WWII undid many of the earlier gains in open space creation. Very little of the green space created during this period exists today.

During the country's economic boom of the 1950s, legislation for the protection of green space became lax. Economic competitiveness was again prioritized over resilient planning and green space preservation (Kumagai et al., 2015; Masuda, 2014). Tokyo's downtown core continued to develop with "little attention to the quality and accessibility to green spaces on the outskirts" (Kumagai et al., 2015, p. 1025). Areas on the fringes of Tokyo were built up with "densely packed, low quality dwellings, many of which remain today" (Kumagai et al., 2015, p. 1025).

\section{Disaster Prevention and Scale}

The relationship between large-scale and small-scale urban planning initiatives is a dominant narrative in the literature on urban planning in Japan (e.g., Evans, 2002; Hein, 2002; Kobayashi, 2007; Kusakabe, 2013). Japanese urban planning "has generally been considered a highly centralized top-down process" (Evans, 2002, p. 443). While community consultation in the planning process is common in Europe and North America, Sorensen (2002) acknowledges that this has not always been the case in Japan. 
In Japan, small-scale urban design that is largely driven by citizens and community organizations is referred to as machizukuri (community building), while large urban planning that deals with the city scale is called toshikeikaku (urban planning) (Flüchter, 2003). Hein (2002) comments that toshikeikaku is equivalent to American and European urban planning, and is primarily focused on "physical structure and planning strategy"(p. 222).

\section{Toshikeikaku: Large Scale Urban Planning}

In 1964, a magnitude 7.4 earthquake struck the Niigata Prefecture located on the coast of the Sea of Japan (approximately $350 \mathrm{~km}$ north/west of Tokyo). Despite the distance, the earthquake “...had considerable impact on Tokyo and radical impacts on policy development" (Flüchter, 2003, p. 217). Tokyo's Kôtô Ward, located in a delta at the confluence of two rivers, suffered the most damage from the Niigata earthquake. Flooding and liquefaction caused widespread building collapse in the densely constructed area (Flüchter, 2003). In response to the damage, a proposal was put forward to develop “...disaster-prevention bases in the endangered area" (Flüchter, 2003, p. 217).

The terminology used to describe these bases varies. Most sources use disaster refuge, relief, or prevention base or park (e.g., Masuda, 2014). The terminology found in Chinese journal articles, however, is much less constant (see Appendix E). The Tokyo Metropolitan Government (TMG) almost exclusively uses the term Disaster Prevention Park and countries like Taiwan have followed suit and adopted the term (Huang \& Chu, 2016). For the purpose of the following discussion, the term Disaster Prevention Park (DPP) will be used.

\section{4 | The Disaster Prevention Parks of Japan}

Masuda (2014) defines a DPP as an urban park that has been designed to "...function as staging grounds for reconstruction and renovation, transfer stations for materials and supplies, or temporary shelters" (p. 53). Flüchter (2003) provides further details in specifying that DPPs require a "minimum of 10 hectares of open space" (p. 217), have measures in place to control flooding and be surrounded by high-rise buildings to serve as firebreaks. In addition, DPPs are to include emergency infrastructure and must have a supply storehouse containing "water for drinking and for firefighting, food, [and] medical supplies" (Flüchter, 2003, p. 217).

Although funding issues prevented construction of the initial DPP proposed in 1965, just 4 years later the TMG began a second iteration of planning for the Kôtô delta area that included six 
DPPs (Flüchter, 2003; Matsuda, 1990). To date, only two of the six DPPs have been completed, Shirahige Higashi Disaster Prevention Park in 1986 (Murao, 2008) and Tokyo Rinkai Disaster Prevention Park in 2011 (The Tokyo Rinkai Disaster Prevention Park, n.d.-c).

Flüchter (2003) questions this model of disaster prevention, popular in the 1960's-70's. Both from an economic and ecological standpoint DPPs are “...decreasing in relative importance, because they no longer appear sustainable" (Flüchter, 2003, p. 234). Accessibility of the DPPs has also been a long-standing issue, with an insufficient network of emergency routes that do not provide for timely evacuation to the parks (Flüchter, 2003). Despite the large scale and economic investment in DPP projects, there is a lack of academic literature detailing how the parks have performed during emergencies, or conversely how they are used in normal times.

\section{Machizukuri: Small Scale Community Building Initiatives}

The term machizukuri appeared in the 1950s and described neighbourhood regeneration initiatives led by citizens. Machizukuri started to gain popularity during the environmental movement of the 1960s and 1970s (Kusakabe, 2013). During the 1980s, these citizen groups were formalized, evolving into machizukuri councils (machizukuri kyôgikai), whose job was to provide a channel for residents to better communicate their needs to the government (Flüchter, 2003). In the 1990s, development projects that made sweeping changes to the streetscape further galvanized these groups (Kusakabe, 2013).

Although Flüchter (2003) refers to these machizukuri councils as operating on the micro-scale, while toshikeikaku is defined by macro-scale, Kusakabe's (2013) analysis is less polarizing, stating that machizukuri councils operate on a number of different levels from the regional down to neighbourhood. Projects undertaken by the councils can involve a number of players from "citizens, city officials and in some cases planners, consultants and researchers" (Kusakabe, 2013, p. 7).

The relationship between toshikeikaku and machizukuri is perhaps most visible during the reconstruction of Kôbe after the 1995 earthquake (Hein, 2002; Kusakabe, 2013). Known as the Hanshin Earthquake, the 7.2 M tremour caused massive damage to supposedly earthquakeproof buildings and infrastructure (Edgington, 2010). Although fires followed the earthquake, unlike the Great Kanto Earthquake, "the majority of the destruction was due to collapsed structures and building damage" (Masuda, 2014, p. 53). In the aftermath of the earthquake, 
reconstruction efforts were largely top down, driven by the government whose focus was infrastructure, modernization, and ensuring a quick return to normalcy for Kôbe residents (Bryant \& Allan, 2013; Hein, 2002). The government-driven recovery however, proceeded with "limited public-participation" (Edgington, 2010, p 105), leading to conflict between government and residents.

Just two months after the disaster, Kôbe's redevelopment plan was approved by the city planning department (Evans, 2002). Residents were given a two-week window in which to review plans for the reconstruction, many of which proposed completely reconfiguring entire districts and required residents to donate portions of their property for widening of streets. This consultation period came at a time when most people were still grieving, displaced and living in shelters (Edgington, 2010; Evans, 2002). It was this “...somewhat inhumane response of the national government" (Bryant \& Allan, 2013, p. 190) in the post-disaster environment which served to mobilize machizukuri councils.

Machizukuri councils are involved with a broad range of initiatives from negotiating land use, building height restrictions and neighbourhood landscape improvement, to social welfare and small-scale place-making (Sorensen \& Funck, 2007). Bryant and Allan (2013) focus on the latter and consider examples of parks in Kôbe developed by machizukuri councils in the aftermath of the 1995 earthquake; the parks address both everyday uses and "the social need for the community to be self-sufficient for the next disturbance" (Bryant \& Allan, 2013, p. 192).

\section{Machizukuri Council Parks}

Described by Bryant and Allan (2013) as "the ultimate community park" (p. 192), Rokko Kaze No Sate Koen is located in the dense urban area to the east of Kôbe's central business district. Because of the amount of research and public engagement, it took the community seven years to complete the designs for the park. In the end, the park both stands as "physical memorial of the crisis that passed" (p. 193) and enhances local resilience to future disaster. The park includes a number of design elements that function both in daily life and disaster. Seating was designed to be converted into cooking facilities or toilets, and plantings focused on species that were edible. Water also featured heavily in the park design, with play areas that incorporated ponds, wells and water pumps in anticipation of future fires (Bryant \& Allan, 2013). 
Minato No Mori, a three-hectare urban park in Kôbe's downtown, was constructed on an abandoned rail yard. The park is dominated by a large field that provides flexibility of use, while more-programmed areas are located on its periphery. In addition to a memorial for earthquake victims, the park also provides features to assist residents facing future disasters such as "a place for gathering and camping, an elevated area for viewing problems, water tanks and place for food security" (Bryant \& Allan, 2013, p. 195).

Located in Nagata Ward, Komagabayashi cho 1 chōme, is the most modest example of machizukuri council park design. Although there was little damage in the traditional residential area, the community "rehabilitated their alleyways with signs for safety and developed a pocket park in one of the disused lots" (Bryant \& Allan, 2013, p. 197). Although the space was no bigger than $400 \mathrm{~m}^{2}$, the lot was transformed into an unassuming community space. The pocket park contained a handful of trees for refuge and shade, a water pump, a small flat open space and a single seat. Like the CIOS initiatives in Christchurch, New Zealand, Bryant and Allan (2013) suggest that encouraging "communities to change the physical fabric of their neighbourhoods in innovative ways" (p. 198) in the post-disaster environment may have a "significant psychological impact" (p. 198) on a community's resilience.

Since The Great Kanto Earthquake of 1923, there has been an evolution of green space and parks in disaster response and recovery. Japan was tested again on March 11, 2011, with a much more complex set of three disasters: earthquake, tsunami and resulting nuclear disaster at the Fukushima Daiichi Nuclear Power Plant. With more large-scale disasters to come, "integrated planning and construction of disaster prevention landscapes will only become more important" (Masuda, 2014, p. 57).

\section{5 | China and The Disaster Prevention Park Model}

Although large-scale DPPs appear to be becoming less relevant in Japan with more emphasis placed on community-led projects (Flüchter, 2003,), China has shown a great deal of interest in the Japanese DPP model. Scholarly work from China almost exclusively refers to Japan as a precedent for disaster mitigation and prevention (e.g., Bao \& Chen, 2004; Jia et al., 2008 ; Jang, Li, Zheng, \& Zhang, 2004 ; Yao et al., 2015; Wu \& Liu, 2013).

Beijing appears to have been the first city in China to specifically address the role of open space in mitigating disaster. In 2001, the City released new legislation (Measures of Beijing 
Municipality for the Implementation of the Law of the People's Republic of China on Protecting against and Mitigating Earthquake Disasters) which stipulated that consideration be given to "necessary lawns, squares and vacant places" (Beijing Government, 2001) to facilitate evacuation and shelter in the event of an earthquake. Li (2014) and Yao (2015) also make reference to the Beijing City Park Ordinance, introduced in 2002. In addition to parks providing functions ranging from ecological, aesthetic and recreational, the ordinance states that they must also play a role in disaster prevention, specifically providing shelter for displaced people (Li, 2014; Yao et al., 2015).

In 2003, China's first DPP was established. The Yuan Dynasty Dadu City Wall Park in Beijing became a model for the development of similar parks in other major cities across China (Li, 2014). The narrow park runs along the ruins of the northern wall of the Yuan Dynasty, and is divided into seven areas that contain emergency power, sanitation, storehouses and emergency services (including fire protection, transportation and communication) (China Daily, 2004; Li, 2014).

In 2008, the 7.9 M Wenchuan earthquake rocked the Province of Sichuan, China. The earthquake and its secondary disasters (primarily building collapse and landslides) killed over 80,000 people and displaced millions. The earthquake was reported to be "one of the largest earthquakes in human history in terms of socio-economic losses" (Daniell, 2013). Shortly after the event, there was a proliferation of scholarship that examined the relationship between parks and disaster mitigation in Wenchuan and surrounding cities affected by the earthquake (e.g., Qui \& Gu, 2008; Jiang et al., 2008; Jia, Liu, Tang, Wu, \& Zhao, 2008 ; Liu, Lin, \& Wang, 2014; Jiang, Shi, \& Li, 2008). Qui and $\mathrm{Gu}$ (2008) also highlight an increase in research by the landscape architecture profession, specifically in respect to the planning and construction of urban green space for disaster reduction.

Fan et al., (2012) Jiang et al. (2008), Li and Zhang (2010) and Yao et al. (2015) found that green space and DPPs in China fell short in providing for the population. Jiang et al. (2008) assessed four DPPs in Chengdu City, concluding that the parks lacked basic emergency facilities. Li and Zhang (2010) assessed the distribution and accessibility of parks in Harbin City China. Their GIS analysis showed that less than $30 \%$ of the areas surrounding the parks in the study could be easily accessed post-disaster. Yao et al. (2015) also commented on the general lack of shelter after the earthquake, and highlighted that the distance to reach shelter was too great. 
After the devastation of the Wenchuan earthquake, "disaster prevention, preparation, and response have become one of the most important considerations for new urban construction" (Li, 2014, p. 47). In response to the earthquake, a document was issued by the PRC Ministry of Housing and Urban-Rural Construction which listed a number of requirements for open space, including improving existing green space for earthquake resilience (Li, 2014, p. 47).

Despite the advances made by Beijing during the early 2000's, the flurry of publications after the 2008 Wenchuan earthquake, and new government legislation, researchers still identify a lack of standardization and implementation of DPPs (e.g., Fang, 2011; Li, 2014; Yao et al., 2015). In a review synthesis of green space and its role in disaster prevention from 2001-2010, Fang et al. (2011) conclude that China lacks a consistent national standard for the planning of DPPs. Yao et al. (2015) also identify "a lack of requirements for the urban disaster prevention green space planning"(p. 1212). Li (2014) acknowledges that most parks still lack the facilities necessary for disaster prevention, and that "China still has a long way to go to achieve disaster prevention and reduction standards seen in other countries" (p. 49).

\subsection{Mitigation in the Absence of Past Disaster}

Unlike China and Japan, certain parts of the world have not experienced the same severity of earthquakes, despite being located in areas of seismic vulnerability. As an example, although a large portion of the population in British Columbia (B.C.), Canada, resides in "a highly active earthquake zone" (Auditor General of British Columbia, 2014, p.12), the Province “...has never experienced a catastrophic earthquake in a densely populated urban centre..." (Auditor General of British Columbia, 2014, p.17). Subsequently, B.C. has not had the same feedback as parts of Asia that are frequently challenged to revise their earthquake resilience strategies.

In 2015, the City of Vancouver, B.C., introduced a network of 25 Disaster Support Hubs located throughout the city. The initiative was based on experience from the Christchurch, New Zealand earthquakes (Robertson, 2015). Citizens in Vancouver are encouraged to incorporate these Hubs into their emergency preparedness plans as places to gather immediately following an earthquake, in order to connect with neighbours and share resources. City staff and volunteers will also be deployed to these Hubs to provide basic services and information. However, their arrival could be delayed by days or weeks after the initial earthquake (City of Vancouver, 2017). 
The majority of the Disaster Support Hubs are located in community centres that have adequate open space for residents to gather and use for shelter in the event that facilities are damaged in the earthquake (City of Vancouver, 2017). Although they will help facilitate community self reliance, the Hubs will "simply be designated spaces in which members of the community can gather after an earthquake" (Robertson, 2015, p 49).

As China and Japan have demonstrated, designing open space to support disaster resilience has evolved with every disturbance. Without the roots of vulnerability having first been exposed through disaster, cities like Vancouver, B.C., must rely on the experiences of other regions to inform their disaster mitigation strategies. The systematic review process, discussed in the following chapter, aims to consolidate research and build a broader foundation of precedents to assist cities like Vancouver in achieving greater seismic resilience. 


\section{CHAPTER 3 | METHODS}

The scope of research related to public open space and seismic resilience encompasses many disciplines. Research review methods are able to recognize patterns and trends across a wide range of literature, and are a critical first step in the planning and design of new interventions (Haddaway \& Bayliss, 2015; Petticrew \& Roberts, 2006). A systematic review of the literature is needed in order to identify ways that open space can be planned, designed and retrofitted to support survival and recovery in the aftermath of major earthquakes.

Through a systematic review process, one locates, summarizes and consolidates research results in a manner that is both transparent and replicable (Palermo, 2013). Although there is no single method for conducting a systematic review (Palermo, 2013), a number of guidelines exist that detail preferred review methods.

Although the systematic review has its roots in the medical field (Torgerson, 2003), it has proven to be an effective method for other disciplines, for example, conservation and environmental management (e.g., Pullin \& Stewart, 2006) and computer science (e.g., Breivold, Crnkovic, \& Larsson, 2012). In recent years, a number of social science and medical journals have changed their submission criteria and will now only accept systematic reviews (Palermo, 2013).

Petticrew \& Roberts (2006) acknowledge that there have been questions about the usefulness of a systematic review in an area of research still in its infancy. However, even uncovering an absence of literature can "in itself [be] an important contribution" (Petticrew \& Roberts, 2006, p. $35)$, and help to identify areas for future research. Ultimately the use of a systematic review will contribute to the growing scholarship in the discipline of evidence-based landscape architecture (Brown \& Corry, 2011).

\section{1 | Search Strategy}

As this area of research is underdeveloped, studies already identified in the literature review were also incorporated in the systematic review. Both grey literature and peer reviewed academic papers were included. Grey literature focused on government papers and professional association or design firm reports. Haddaway \& Bayliss (2015) refer to this form of grey literature as "practitioner-generated research" (p. 827). 
Electronic searches were carried out in July, 2017, using the following databases;

- ProQuest Databases _ - Google Scholar

- Web of Science - Google

Articles from the literature review informed the following table of search terms. Search strings that combined these terms were used to locate literature.

Table 1: Search Terms

\begin{tabular}{|llll|}
\hline DISASTER & EMERGENCY CYCLE & SPACE TYPE & DISCIPLINE \\
Disaster & Mitigation & Green Space & Emergency Management \\
Emergency & Planning & Garden & Landscape Architecture \\
Hazards & Prevention & Landscape & Urban Planning \\
Risk & Preparedness & Open Space & Urban Design \\
Earthquake & Response & Plazas & \\
Seismic & Recovery & Parks / Parkland & \\
& Reconstruction & Public Space & \\
& Resilience & Streets & \\
& & & \\
& & & \\
\hline
\end{tabular}

\section{2 | Study Selection}

The systematic review inclusion criteria were purposefully broad in order to take "...account of a multiplicity of possible interventions" (Petticrew \& Roberts, 2006, p. 74). Haddaway and Bayliss (2015) also note that a broader approach will generate more reliable results and further increase the reviewer's ability to pinpoint patterns and trends in the literature. As a result, articles were not excluded based on their date of publication or study approach. The Cochrane Collaboration guidelines were adapted to inform the systematic review structure (see Higgins \& Green, 2011).

Articles were required to meet the following criteria for inclusion:

Stage 1: Title and Abstract Review

- Academic Literature: Terms from the Search Terms list appear in the title, abstract or keywords.

- Grey Literature: Terms from the Search Terms list appear in the title, executive summary, first two paragraphs of text and/or the database has located a search term embedded within the document.

- Full text is available in English 
Stage 2: Full Text Review

- Documents must specifically address elements of open space for mitigation, preparedness, response or recovery in relation to a hazard, risk or disaster.

- Academic literature must adhere to basic citation protocol.

\section{3 | Final Article Selection}

Bibliographic information from articles that met the criteria was entered into the citation manager Zotero. A snowball search of the final article's references was conducted and relevant sources that were not identified in previous searches were incorporated. In total, 35 documents were retained for final analysis (see Table 2 for final article summary).

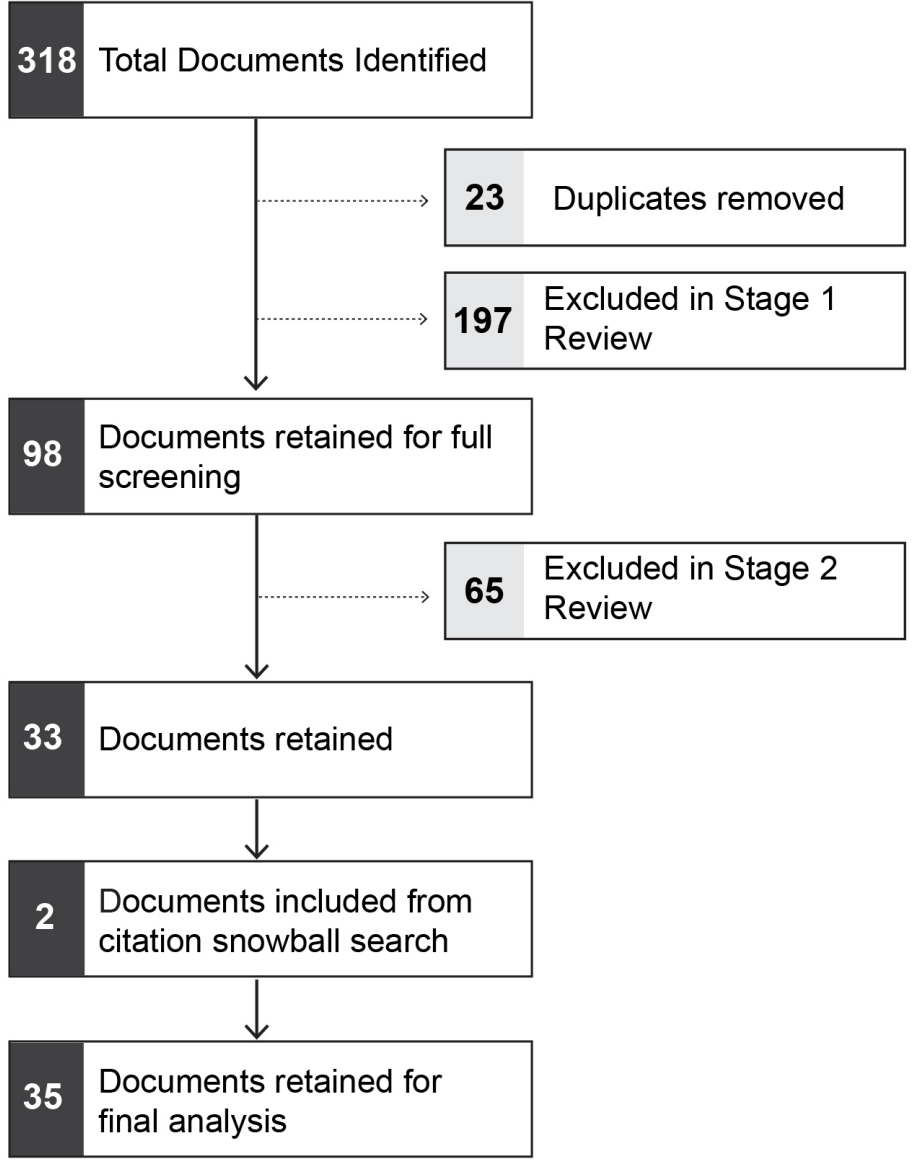

Figure 4: Systematic Review Study Selection 
Table 2: Final Article Summary

\begin{tabular}{|c|c|c|c|c|c|c|c|c|}
\hline \# & REFERENCE & $\begin{array}{l}\text { RESOURCE } \\
\text { TYPE }\end{array}$ & HAZARD & $\begin{array}{l}\text { REGION(S) OF } \\
\text { FOCUS }\end{array}$ & \multicolumn{4}{|c|}{$\begin{array}{l}\text { EMERGENCY } \\
\text { CYCLE }\end{array}$} \\
\hline & & & & & $\begin{array}{l}\mathrm{M} \\
\mathrm{T}\end{array}$ & $\begin{array}{l}\mathrm{P} \\
\mathrm{R}\end{array}$ & $\begin{array}{l}R \\
S\end{array}$ & $\begin{array}{l}\mathrm{R} \\
\mathrm{C}\end{array}$ \\
\hline 1 & Ahern (2011) & Journal Article & All-Hazards & N/A & $\mathrm{X}$ & & & \\
\hline 2 & $\begin{array}{l}\text { Allan \& Bryant } \\
(2010)\end{array}$ & Conference Paper & Earthquake & San Francisco, U.S. & & & & $\mathrm{X}$ \\
\hline 3 & $\begin{array}{l}\text { Allan \& Bryant } \\
\text { (2011) }\end{array}$ & Journal Article & Earthquake & $\begin{array}{l}\text { San Francisco, U.S. } \\
\text { Concepcón, Chile }\end{array}$ & $x$ & & $\mathrm{X}$ & $\mathrm{X}$ \\
\hline 4 & Allan et al. (2013) & Journal Article & Earthquake & Concepcón, Chile & $\mathrm{X}$ & & $\mathrm{X}$ & $\mathrm{X}$ \\
\hline 5 & $\begin{array}{l}\text { Allan \& Bryant } \\
(2014)\end{array}$ & Journal Article & Earthquake & $\begin{array}{l}\text { San Francisco, U.S. } \\
\text { Concepcón, Chile }\end{array}$ & $x$ & & $\mathrm{X}$ & $X$ \\
\hline 6 & $\begin{array}{l}\text { Anhorn \& Khazai } \\
(2015)\end{array}$ & Journal Article & Earthquake & Kathmandu, Nepal & $x$ & & & \\
\hline 7 & Bahrainy (1998) & Journal Article & Earthquake & Rasht, Iran & $\mathrm{X}$ & & & \\
\hline 8 & $\begin{array}{l}\text { Bryant \& Allan } \\
(2013)\end{array}$ & Book Chapter & Earthquake & $\begin{array}{l}\text { Christchurch, } \\
\text { New Zealand } \\
\text { Kôbe, Japan }\end{array}$ & & & & $\mathrm{X}$ \\
\hline 9 & $\begin{array}{l}\text { Campbell, } \\
\text { Svendsen, Sonti, \& } \\
\text { Johnson (2016) }\end{array}$ & Journal Article & Hurricane & New York City, U.S. & $x$ & & & $\mathrm{X}$ \\
\hline 10 & $\begin{array}{l}\text { Chan, DuBois, \& } \\
\text { Tidball (2015) }\end{array}$ & Journal Article & Hurricane & New York City, U.S. & & & & $\mathrm{X}$ \\
\hline 11 & $\begin{array}{l}\text { CMG Landscape } \\
\text { Architecture. (2017) }\end{array}$ & Website & Earthquake & San Francisco, U.S. & $\mathrm{X}$ & $X$ & $\mathrm{X}$ & $X$ \\
\hline 12 & $\begin{array}{l}\text { Dionísio et al. } \\
(2012)\end{array}$ & Journal Article & $\begin{array}{l}\text { Earthquake } \\
\text { Fire }\end{array}$ & $\begin{array}{l}\text { Tokyo \& Kobe, } \\
\text { Japan }\end{array}$ & $x$ & $x$ & & \\
\hline 13 & Flüchter (2003) & Journal Article & Earthquake & Tokyo, Japan & $x$ & & & \\
\hline 14 & $\begin{array}{l}\text { Government of } \\
\text { Nepal, \& IOM. } \\
\text { (2011) }\end{array}$ & Report & Earthquake & Kathmandu, Nepal & $x$ & & & \\
\hline 15 & Ishikawa (2002) & Journal Article & $\begin{array}{l}\text { Earthquake } \\
\text { Fire }\end{array}$ & Tokyo, Japan & $x$ & & & \\
\hline 16 & $\begin{array}{l}\text { León \& March } \\
\text { (2014) }\end{array}$ & Journal Article & $\begin{array}{l}\text { Earthquake } \\
\text { Tsunami }\end{array}$ & Talcahuano, Chile & $x$ & & $\mathrm{X}$ & \\
\hline 17 & $\begin{array}{l}\text { León \& March } \\
\text { (2016) }\end{array}$ & Journal Article & $\begin{array}{l}\text { Earthquake } \\
\text { Tsunami }\end{array}$ & Iquique, Chile & $\mathrm{X}$ & & $\mathrm{X}$ & $X$ \\
\hline 18 & Li et al. (2017) & Journal Article & Earthquake & Shanghai, China & $\mathrm{X}$ & & & \\
\hline 19 & Li (2014) & Paper & Earthquake & China & $\mathrm{X}$ & & & \\
\hline 20 & Liu et al. (2014) & Journal Article & Earthquake & $\begin{array}{l}\text { Wenchuan County, } \\
\text { China }\end{array}$ & & & & $X$ \\
\hline 21 & Masuda (2014) & Paper & Earthquake & Japan & $\mathrm{x}$ & & & \\
\hline 22 & Matsuda (1990) & Journal Article & $\begin{array}{l}\text { Flooding } \\
\text { Earthquake }\end{array}$ & Tokyo, Japan & $x$ & & & \\
\hline 23 & $\begin{array}{l}\text { Mazereeuw \& } \\
\text { Yarina (2017) }\end{array}$ & Journal Article & All-Hazards & N/A & $x$ & $\mathrm{X}$ & & \\
\hline 24 & $\begin{array}{l}\text { Okvat \& Zautra } \\
\text { (2014) }\end{array}$ & Book Chapter & All-Hazards & $\mathrm{N} / \mathrm{A}$ & $x$ & & & $\mathrm{X}$ \\
\hline 25 & $\begin{array}{l}\text { Park, Takeda, } \\
\text { Kaga, \& Masuda } \\
\text { (2016) }\end{array}$ & Journal Article & All-Hazards & Kôbe, Japan & $\mathrm{x}$ & & & \\
\hline
\end{tabular}




\begin{tabular}{|c|l|l|l|l|l|l|l|l|}
\hline$\#$ & \multicolumn{1}{|c|}{ REFERENCE } & \multicolumn{1}{|c|}{$\begin{array}{c}\text { RESOURCE } \\
\text { TYPE }\end{array}$} & HAZARD & \multicolumn{2}{|c|}{$\begin{array}{l}\text { REGION(S) OF } \\
\text { FOCUS }\end{array}$} & \multicolumn{2}{|c|}{ EMERGENCY } \\
CYCLE
\end{tabular}

MT - Mitigation, PR - Preparedness, RS - Response, RC - Recovery 


\section{CHAPTER 4 | RESULTS}

The literature identified through the systematic review covers a broad range of topics on both the physical and social impacts of disaster. The overarching themes of multifunctionality and resilience appear throughout the results on all scales, from regional or citywide networks of open space to individual sites. The literature also reveals planning and design strategies to meet basic human needs such as water, food and sanitation, as well as qualitative environmental improvements to enhance open space function after disaster. Open space programming, education and community engagement are also shown to be critical in the planning, design and proper function of open space for disaster resilience.

The following section addresses designing multifunctional open spaces with embedded disaster resilience that can adapt to different needs and conditions in the aftermath of an earthquake. Allan and Bryant (2010) refer to these multifunctional open spaces as a "second city" (p. 34), which both contribute to daily life and have the capacity to support response and recovery needs after disaster.

\section{1 | Multifunctionality and Embeddedness}

Multifunctionality in public open space creates a culture of resilience and contributes to building resilient communities (León \& March, 2014; Villagra-Islas \& Dobbie, 2014). These multifunctional or hybrid open spaces can act as "leading components of emergency response" (Turer Baskaya, 2015, p. 741). Further, Mazereeuw \& Yarina (2017) and Allan et al. (2013) note that the more embedded disaster resilient design and function are in daily life, the more effective they will be in the aftermath of disaster.

Because of the unpredictable nature of disasters, funding retrofits or leaving open space undeveloped can be economically difficult to justify. However, designing open space for disaster should not be seen as a constraint, but an opportunity to enhance the overall quality of the urban environment (Allan \& Bryant, 2011; León \& March, 2016; Masuda, 2014; Mazereeuw \& Yarina, 2017)

The design concept developed by Hyphae Design Laboratory and CMG Landscape Architecture in 2014, for the Resilient SF Design Challenge, illustrates the alignment of both emergency and non-emergency design goals. The Golden Gate Park polo fields in San Francisco were the 
focus of the project. As Allan and Bryant (2011) and Allan et al. (2013) demonstrated, parks played a critical role in response and recovery after the Great San Francisco Earthquake of 1906. Golden Gate Park in particular was the site of a large refugee camp for displaced residents (Henderson, 2006). The design team drew on these historic roots for inspiration and proposed reinforcing the park with different layers of sustainable infrastructure (CMG Landscape Architecture, 2017).

In addition to the site's daily uses, it also hosts festivals and concerts throughout the year. The project team found that both the needs of festivals and concerts aligned with the 72-hour period that citizens are asked to prepare for in the aftermath of disaster when they are likely to be cutoff from life-lines. Those life-lines (shelter, food, water, power, waste management etc.) are also required for the concerts and festivals which the park hosts, and which also typically last for three days (CMG Landscape Architecture, 2017).

\section{2 | Resilience}

Despite the alignment of projects goals that CMG Landscape Architecture was able to achieve, urban design and recovery planning tend to be disconnected. Allan and Bryant $(2011,2014)$ and Allan et al. (2013) use the theory of resilience as a means of unifying the two disciplines, ensuring that day-to-day planning and design decisions "automatically create opportunities to facilitate effective recovery" (Allan and Bryant, 2010, p. 3).

As Allan et al. (2013) establish, literature linking open space and resilience is scarce and often not referred to directly. To complicate things further, there are also many definitions of resilience depending on the field of application (e.g., engineering, ecology, sociology). However, the definition of resilience as defined by Walker and Salt (2006) was most frequently cited in the review articles.

Walker and Salt (2006) define resilience as, "the capacity of a system to absorb disturbance; to undergo change and still retain essentially the same function, structure and feedbacks" (Walker \& Salt, 2006, p. 31). The authors outline nine attributes of resilience: diversity, variability, modularity, acknowledging slow variables, tight feedbacks, social capital, innovation, overlap in governance, and ecosystem services. 
Allan and Bryant (2014) see these attributes as useful for informing the design of resilient cities to enhance recovery following an earthquake. The attributes of redundancy and connectivity (as it relates to multi-scale networks) were frequently mentioned in the literature. However, the two most commonly discussed resilience attributes were diversity and modularity.

\section{Diversity}

In order to function both pre- and post-disaster, systems of open space need to be designed for diversity (Ahern, 2011; Allan et al., 2013; Dionísio, Candeia de Souza, \& Ota, 2012; Villagra et al., 2014). It may initially seem that the most adaptable open space would be uniform or homogenous, but these types of spaces "offer reduced opportunities for adaptation" (Allan et al., 2013, p. 258). Large areas of unstructured land create a dispersed urban form, which makes achieving sustainable and vibrant community design difficult (Allan \& Bryant, 2010).

\section{Modularity and Redundancy}

Mazereeuw \& Yarina (2017) observe that infrastructure is seldom designed for "worst-case disaster scenarios" (p. 66). The strategies of modularization and redundancy provide protection from the vulnerability inherent in centralized systems (Ahern, 2011; Allan et al., 2013). In the event of systems failure, modularization and redundancy ensure that backups are in place and that risk is more evenly distributed (Ahern, 2011; Villagra et al., 2014).

\section{3 | Networks \& Connectivity}

While open space for disaster resilience should operate as a self-contained module, it must also function on the scale of the collective (Allan \& Bryant, 2011). Improvements to a city's network of open space can increase a community's ability to respond to earthquakes through a reduction in evacuation times (Allan et al., 2013; León \& March, 2016). Lack of a well-planned evacuation network can undermine the function of open space during disaster. Networks that provide alternative connections increase resilience through redundancy. In the event that a connection is severed during a disaster, connectivity is maintained (Ahern, 2011; Bahrainy, 1998; Tumini et al., 2017).

Networks also need to be designed for accessibility and ensure that they have the capacity to avoid congestion in densely-populated areas after an earthquake (Bahrainy, 1998). León and 
March (2014) also stress that a key priority when planning networks is to connect vulnerable areas (physical or social) with safe open spaces.

In Iquique, Chile, León \& March (2016) found that even when applying best-case scenarios for evacuation from a tsunami following a seismic event, areas that were vulnerable were unable to complete the evacuation in the 20-minute time period before the arrival of the tsunami. Evacuation routes to safe refuge were too long, poorly maintained and had issues with accessibility (e.g., stairs, parked cars, businesses and restaurants blocking streets). Buildings, signs, electrical wiring and balconies that were vulnerable to collapse during an earthquake also bordered the streets.

\section{Scale}

Networks of open space must also function on multiple scales (Ahern, 2011; Allan \& Bryant, 2011; Li, 2014; Turer Baskaya, 2015). Planning and design for seismic resilience should consider the regional, metropolitan, city, sector and project scale (Bahrainy, 1998). In Japan, green networks address this hierarchy of scale and are designed to operate on the regional, city and sector (or neighbourhood) level to facilitate evacuation of residents to DPPs, provide access for emergency vehicles, and act as a buffer to stop the spread of fire (Ishikawa, 2002; Park et al., 2016). Here, both the conventional street network and corridors of urban green space are designed to connect individual parks (Masuda, 2014).

\section{4 | Distribution \& Grouping}

In addition to connecting open space with well planned networks, the distribution of open space along these networks is of critical importance (Pizzo et al., 2014; Turer Baskaya, 2015). Although Japanese planning guidelines suggest that open space should be positioned every two kilometers (Masuda, 2014; Park et al., 2016), others such as Villagra et al. (2014) encourage diversity in spatial distribution.

Bahrainy (1998) recommends decentralizing city centres to avoid concentrating risk, and locating open space adjacent to these dispersed centres to reduce issues with emergency response. Open spaces should also be located in such a way as to create nodes with critical infrastructure and facilities such as hospitals, emergency services and transportation, thus aiding response time during disaster (Anhorn \& Khazai, 2015; Turer Baskaya, 2015; Villagra et 
al., 2014). In addition to grouping open space with facilities, Turer Baskaya (2015) also discusses the concept of clustering open space in order to increase its capabilities, either by grouping small open spaces close together, or small spaces around a larger open space.

\section{5 | Site Location \& Suitability}

When determining the location of open space for disaster resilience it is critical to first identify areas that are exposed to risk (Anhorn \& Khazai, 2015; Bahrainy, 1998; Tumini et al., 2017). Bahrainy (1998) stresses the importance of using seismic microzonation maps to determine specific areas of seismic activity and potential for secondary hazards (e.g., landslide, liquefaction, flooding).

In Chile, although government planning legislation stipulates the amount of open space for use after a disaster, it does not factor risk into this calculation (Tumini et al., 2017). Instead, the legislation bases the provision of public open space on population density. Although the need for public open space rises proportionally with population density (Bahrainy, 1998), Tumini et al. (2017) advise that planning must account for the level of risk faced in each area, while anticipating that areas with low risk exposure will likely need to accommodate an increase in population after a disaster.

Though the avoidance of high hazard areas or of using open space to buffer hazards are common planning tools (e.g., Government of Nepal \& IOM, 2011; Masuda, 2014; Turer Baskaya, 2015), there are situations where locating public open space in areas exposed to hazards may be advantageous. In the aftermath of the Tōhoku Tsunami that followed the 2011 Great East Japan Earthquake, a park system for the coastal city of Iwanuma (approximately 20 km south of Sendai) Miyagi Prefecture, Japan was proposed (Strusińska-Correia, 2017). The project, titled Millennium Hope Hills, consists of a network of six-tsunami disaster prevention parks, connected by raised pathways and protected by forested areas to dissipate the wave's power. Debris from the earthquake and tsunami were used to create 15 hills for vertical evacuation, with each hill able to accommodate 50 evacuees (Strusińska-Correia, 2017).

\section{Scenario Planning}

In addition to assessing risk exposure, it is critical to calculate the number of people expected to require shelter in an area (Anhorn \& Khazai, 2015). In planning for their Golden Gate 
sustainable infrastructure concept, CMG Landscape Architects learned from the 1989 Loma Prieta Earthquake that affected Northern California, displacing 12,000 residents, to create initial design parameters (CMG Landscape Architecture, 2017).

Anhorn \& Khazai (2015) recommend preparing for the "worst case scenario" (p. 790) in which almost all buildings collapse during an earthquake. In this scenario, all evacuation and shelter needs must be met solely by open space in the city. Similarly, The Government of Nepal and IOM (2011) assume dense urban areas will be uninhabitable after an earthquake and open space on the periphery will need to accommodate the majority of displaced residents.

León \& March (2016) used "what-if' scenario analysis" (p. 840) which selects specific parts of a city where interventions can best improve the urban environment for future hazards. The study targeted three neighbourhoods in Iquique, Chile, that had the longest evacuation times and developed modifications specific to those locations that would enhance evacuation.

\section{Site Conditions}

When identifying appropriate areas for the location of open space, León and March (2014) consider characteristics such as area size, slope, land cover and the capacity of the site to support emergency services and infrastructure. Turer Baskaya (2015) note that land with dense vegetation, such as "low canopy trees, shrubs and groundcover" (p. 737) that impede access or prevent shelter from being erected, was negatively correlated with location suitability.

The criterion used by individuals to select open space for use after disaster (as discussed in the literature review) is also helpful to inform site selection. For instance, evacuees tended to occupy areas that had clear sight lines of surrounding areas; were accessible but with defined boundaries; contained infrastructure, facilities and water; had been used previously in disasters; and were in close proximity to their residence (Allan et al., 2013; Villagra-Islas \& Alves, 2016).

\subsection{Size \& Function}

In a report on the identification of suitable open space for camps after major earthquakes, The Government of Nepal and IOM (2011) only considered areas that could hold over 1000 displaced people. It was assumed that smaller open space would be used for "spontaneous camps" (areas settled by displaced population); they reasoned that government and humanitarian efforts would be better applied in supporting camps of a larger size (Government of Nepal \& IOM, 2011, p. 7). 
In Japan, there is a similar opinion that the larger the open space, the more important its perceived value for disaster prevention, while the contribution of small public open spaces to disaster prevention is seen as negligible (Dionísio et al., 2012; Ishikawa, 2002). Small public open spaces are often excluded from disaster prevention plans because they do not have the capacity to support large numbers of evacuees (Dionísio et al., 2012).

Yet, Ishikawa (2002) demonstrates that small parks are indeed heavily used in the aftermath of an earthquake. Dionísio, Candeia de Souza, \& Ota (2012) conclude that integrating small and medium public open spaces into disaster prevention planning would not require large changes to the urban fabric, allowing for the preservation of existing urban form and neighbourhood character. In addition, in areas with a scarcity of open space, even small spaces can be important during a disaster (Dionísio et al., 2012).

In Japan, there is a well-defined hierarchy of open space for use during and after disaster. Masuda (2014) provides information from the Ministry of Land, Infrastructure, Transport and Tourism of Japan in Table 3 below, describing this hierarchy.

Table 3: Disaster Prevention Park Size, Type and Function (adapted from Masuda, 2014, p. 55)

\begin{tabular}{|c|c|c|c|c|}
\hline \multicolumn{3}{|l|}{ FUNCTION } & \multirow{4}{*}{$\begin{array}{l}\text { TYPE } \\
\text { State Park }\end{array}$} & \multirow[t]{4}{*}{ REQUIREMENTS } \\
\hline \multirow[t]{7}{*}{$\begin{array}{l}\text { Command } \\
\text { Post }\end{array}$} & \multirow[t]{3}{*}{$\begin{array}{l}\text { Regional } \\
\text { command post }\end{array}$} & $\begin{array}{l}\text { Headquarters for large- } \\
\text { scale disaster refuge }\end{array}$ & & \\
\hline & & Encampment of aid troops & & \\
\hline & & $\begin{array}{l}\text { Support base for medical } \\
\text { aid }\end{array}$ & & \\
\hline & \multirow[t]{2}{*}{$\begin{array}{l}\text { Urban command } \\
\text { post }\end{array}$} & $\begin{array}{l}\text { Support for rescue, first aid } \\
\text { and lifeline repair teams }\end{array}$ & \multirow[t]{2}{*}{$\begin{array}{l}\text { Large-Scale } \\
\text { Park }\end{array}$} & \multirow[t]{2}{*}{$\begin{array}{l}\text { Larger than } \\
5 \mathrm{~km}^{2}\end{array}$} \\
\hline & & Transfer station for supplies & & \\
\hline & \multirow[t]{2}{*}{$\begin{array}{l}\text { Neighbourhood } \\
\text { command post }\end{array}$} & $\begin{array}{l}\text { Base for rescue and first } \\
\text { aid }\end{array}$ & \multirow[t]{2}{*}{$\begin{array}{l}\text { Major Urban } \\
\text { Park }\end{array}$} & \multirow[t]{2}{*}{$\begin{array}{l}\text { Larger than } \\
1 \mathrm{~km}^{2}\end{array}$} \\
\hline & & $\begin{array}{l}\text { Transfer station for rescue } \\
\text { supplies }\end{array}$ & & \\
\hline \multirow[t]{2}{*}{ Shelter Area } & $\begin{array}{l}\text { Large-scale } \\
\text { shelter }\end{array}$ & $\begin{array}{l}\text { Shelter for residents of the } \\
\text { region }\end{array}$ & $\begin{array}{l}\text { Major Urban } \\
\text { Park, Large- } \\
\text { Scale Park }\end{array}$ & $0.4 \mathrm{~km}^{2}-1 \mathrm{~km}^{2}$ \\
\hline & $\begin{array}{l}\text { Emergency } \\
\text { shelter }\end{array}$ & $\begin{array}{l}\text { Temporary shelter for } \\
\text { neighbourhood residents }\end{array}$ & $\begin{array}{l}\text { Neighbourhood } \\
\text { Park }\end{array}$ & $\begin{array}{l}\text { Larger than } \\
200 \mathrm{~m}^{2}\end{array}$ \\
\hline $\begin{array}{l}\text { Evacuation } \\
\text { Route }\end{array}$ & & & Greenway & $\begin{array}{l}\text { Greater than } \\
10 \mathrm{~m} \text { in width }\end{array}$ \\
\hline
\end{tabular}


While Masuda (2014) notes that the size of open space should be based on an average area of $2 \mathrm{~m}^{2}$ per person, Anhorn and Khazai (2015), Villagra et al. (2014), Tumini et al. (2017) and The Government of Nepal and IOM (2011) use the guidelines provided by The Sphere Project (2011) for minimum humanitarian shelter standards. The Sphere Project advocates for a minimum of $3.5 \mathrm{~m}^{2}$ per person for emergency shelter.

Guidelines on size requirements of open space will change as short-term needs for shelter and services evolve in the days and months that follow a disaster. For example, long-term shelter requires a minimum of $45 \mathrm{~m}^{2}$ per person (The Sphere Project, 2011). Li (2014) and Masuda (2014) stress the need for DPPs to consider these changing requirements.

\section{7 | Site Elements}

\subsection{1 | Water}

The presence of water is a critical attribute, both as a predictor of open space use after disaster (e.g. Villagra-Islas \& Alves, 2016; Villagra-Islas \& Dobbie, 2014) and as a requirement for the location of open space for disaster resilience (Government of Nepal \& IOM, 2011; León \& March, 2014; Turer Baskaya, 2015). In the Kathmandu Valley, Nepal, an estimated 95\% of the water infrastructure is expected to be destroyed in an earthquake (Government of Nepal \& IOM, 2011).

In Tokyo, DPPs are equipped with emergency water-supply tanks and manual water pumps that will function in the event of a power outage (Tokyo Metropolitan Government, n.d.). As Bryant and Allan (2013) observed, smaller machizukuri council parks in Kôbe also incorporated wells, water supply tanks, pumps and water features in the park design. The Golden Gate Park sustainable infrastructure concept proposed the construction of an observation tower that would serve as a viewing platform and function to draw water from the park's aquifer, passively filtering and pressurizing the water for potable use (CMG Landscape Architecture, 2017).

The availability of water is also critical for fire suppression. In the aftermath of the Hanshin Earthquake of $1995,80 \%$ of the wooden housing was destroyed by fire in the Matsumoto district of Kôbe (Ishikawa, 2002). Citizens reflecting on their experience during the earthquake, felt that, had there been more sources of water available to them, there would have been far less 


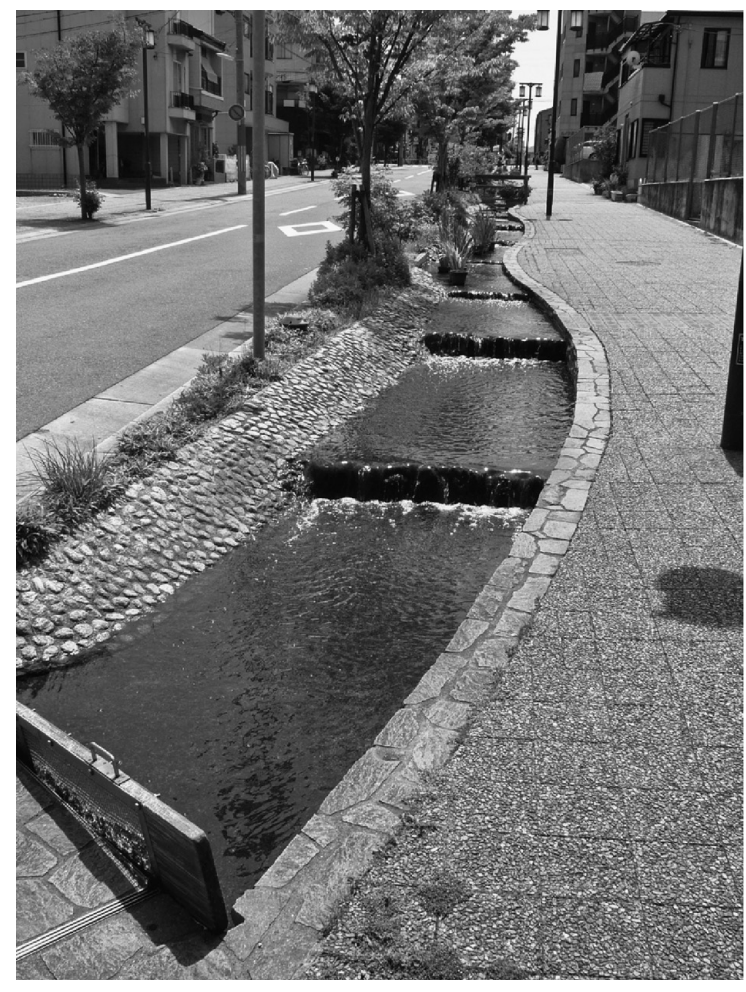

Figure 5: Seseragi Stream - Matsumoto district (Edgington, 2016, p. 128) damage from fires (Ishikawa, 2002). In addition to adding new parks and re-enforcing existing green space, a key component of the reconstruction plan for the centre of the Matsumoto district was the creation of a stream (see Figure 5) incorporated into the city street (Ishikawa, 2002).

\subsection{2 | Sanitation}

The Tokyo Metropolitan Government describes issues with sanitation as one of the most "distressing" (Tokyo Metropolitan Government, n.d., p. 121) during a disaster. Disaster prevention parks in Tokyo are equipped with temporary toilets that directly connect to the sewer systems and do not require water or electricity to function. During a disaster, manhole covers can be fitted with toilet seats and privacy tents erected around each unit (Tokyo Metropolitan Government, n.d.).

Similar emergency sanitation systems were also mentioned in the context of The Yuan Dynasty City Wall Relics Park in Beijing (Li, 2014) and the machizukuri council park Rokko Kaze No Sate Koen in Kôbe (Bryant \& Allan, 2013). The Golden Gate Park sustainable infrastructure concept envisioned a waste management system comprised of composting toilets, and constructed wetlands for the treatment of grey water (CMG Landscape Architecture, 2017).

\subsection{3 | Food}

As Allan and Bryant (2011) described after the 1906 earthquake in San Francisco, residents used campfires or assembled makeshift kitchens in the street to prepare food. In Tokyo and Kôbe, both large DPPs and machizukuri council parks have formalized this function, installing benches or seating that convert into wood burning stoves or cooking pits when the seat top is removed (Bryant \& Allan, 2013; Tokyo Metropolitan Government, n.d.)

After the 2010 Chilean earthquake and tsunami, residents fought over food and water. For people who managed to escape from the city into rural neighbourhoods, vegetable gardens and 
orchards were an important source of food (Allan et al., 2013). Chan, DuBois, and Tidball (2015) discuss enhancing food security after disaster through the development of community gardens.

In the design of Rokko Kaze No Sate Koen, Kôbe, the community selected species of trees with edible fruit in anticipation of needs following disaster. Larger scale DPPs in Japan also include supply storehouses containing, food, water and medical supplies (Flüchter, 2003). Masuda (2014) notes that even small-scale open space should have storage with basic supplies.

\subsection{4 | Power \& Lighting}

Loss of lifelines such as water and power are among the primary reasons for why people evacuate to shelter sites (Li, Zhao, Huang, \& Hu, 2017). After the Chilean earthquake, although power was restored to some areas within four days (Allan et al., 2013), other areas were without power for weeks (León \& March, 2014). To help mitigate this issue, space allocated for solar power generation and solar-powered lighting are standard features of DPPs in Japan (Masuda, 2014; Tokyo Bureau of Construction, n.d.).

In the port city of Talcahuano (14 km northwest of Concepción, Chile), a lack of street lighting had a negative impact on evacuation after the earthquake struck at 3:34 am (León \& March, 2014). León \& March (2014) discuss three types of lighting that could play a role in guiding people to safety during an emergency: beacons (located in safe open space), solar-powered street lighting and backup ground illumination directing people towards open spaces.

\subsection{5 | Wayfinding \& Communication}

Other design interventions to strengthen wayfinding were proposed by León \& March (2014) including themed or colour-coded components of key streets (building facades, street furniture, signage, pavement, etc.) as visual cues to assist evacuees with route selection. In normal times, León \& March (2014) suggest that these cues can help maintain awareness of the area's potential for disaster.

León \& March (2014) also list communication as one of the main objectives for open space design. After a disaster, issues with communication networks will often arise. In Chile, problems with the transmission of critical information from emergency services to residents affected 
evacuation (León \& March, 2014). In Japan, DPPs contain radio broadcasting facilities that are tasked with communicating to the public and coordinating emergency response (Masuda, 2014).

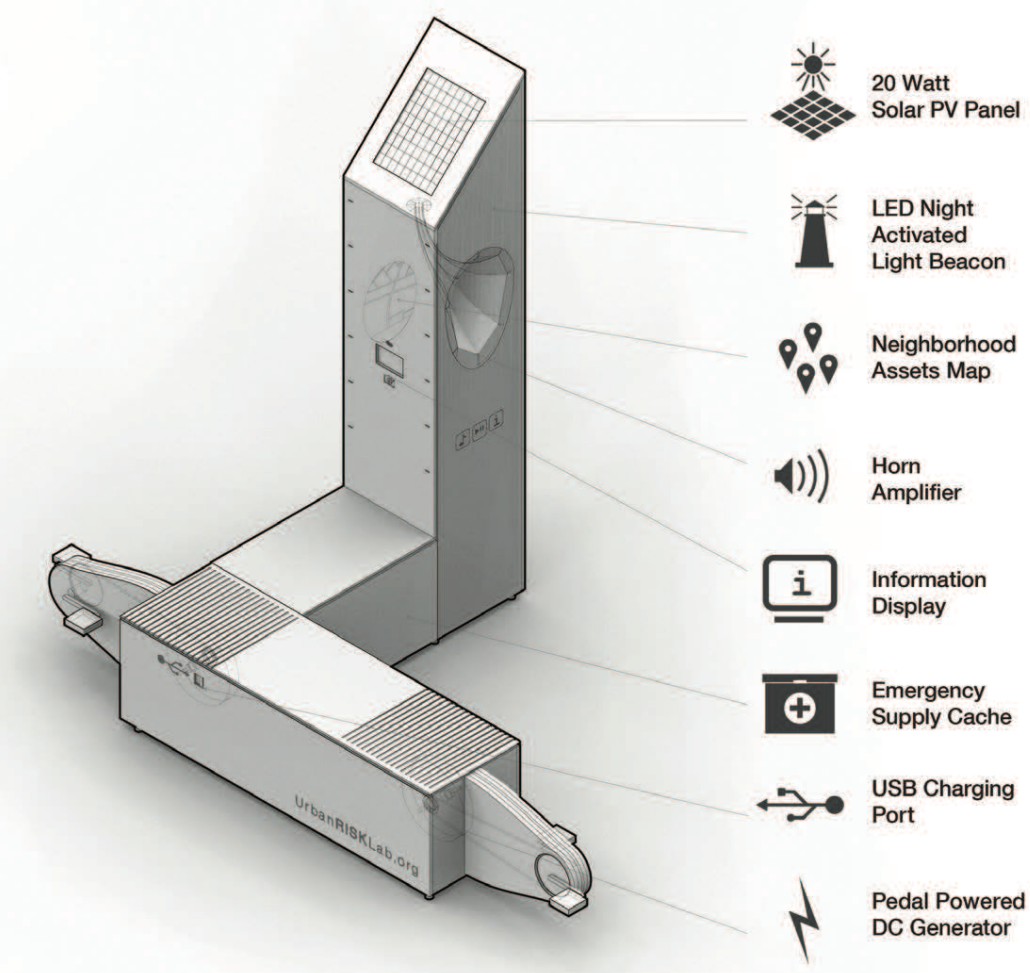

Figure 6: PREPHub Version 1.5 (Mazereeuw \& Yarina, 2017, p. 70)
Mazereeuw \& Yarina (2017) discuss a research prototype that incorporates the elements of wayfinding, communication, power and lighting into modular units that can be installed in public open space and modified according to location and community needs. The Emergency Preparedness Hub (PREPHub) (see Figure 6) developed by the Urban Risk Lab at The Massachusetts Institute of Technology is intended to be distributed throughout a city, forming a network of illuminated

landmarks that guide residents during evacuations. During daily use the PREPHub is an interactive piece of street furniture (Mazereeuw \& Yarina, 2017).

\section{8 | Programming}

While the literature discussed above has primarily dealt with physical resilience broadly, there are studies that connect open space programming to fostering social resilience. Although the majority of articles stem from research on Hurricane Sandy in 2012, they provide insight that can be applied generally to the design of open space for disaster resilience.

Campbell et al. (2016) examined the use of parkland in the Jamaica Bay area of New York City, one year after the hurricane. The study reinforces the concept that parks are important social spaces that support the creation of personal connections and overall sociability. This helps people to "engage in coping strategies against chronic stressors in the urban environment" 
(Campbell et al., 2016, p. 41). The provision of gathering spaces such as seating areas and fire pits encourage people to engage in social activities, in turn creating spaces that encourage increased use. Although the study was site specific, Campbell et al. (2016) see their findings as applying to resilience planning on larger scales (e.g., district and city planning).

Okvat and Zautra (2014) use the Dynamic Model Affect, a theoretical framework that proposes engaging in positive activities, such as gardening in high-stress environments like a disaster zone, can create positive emotions and increase individual and community resilience. As Chan, DuBois, \& Tidball, (2015) noted earlier, after Hurricane Sandy, community gardens in New York City were sources of neighbourhood support, refuge and restoration.

Along with embedding disaster functions into daily life, Okvat and Zautra (2014) and Chan, DuBois, \& Tidball (2015) stress the importance of increasing the social resilience of a community before a disaster. As the authors suggest this will help ensure social networks can be relied upon to provide support during emergency response and recovery. As part of disaster preparedness planning, Okvat and Zautra (2014) suggest creating an "extensive network of community gardens" (p. 73).

\section{9 | Community Engagement}

One of the primary goals outlined by the Tokyo Metropolitan Government for the development of a disaster-proof city is the inclusion of the community in any disaster prevention work, ensuring a sense of ownership and responsibility for its own safety (Matsuda, 1990). Masuda (2014) also stresses that community participation is "essential" (p. 57) in the planning process; it equips residents with better knowledge of local disaster prevention plans and empowers local selfsufficiency.

Although top-down government-led construction projects are efficient in many respects, they often preclude community consultation and engagement with other stakeholders who have important local knowledge and expertise (e.g., Liu et al., 2014). Mazereeuw \& Yarina (2017) note that it is becoming more common for disaster management to incorporate existing frameworks, organizations and infrastructure in disaster mitigation plans. Identifying and fortifying these resources necessitates local level, community engagement (Mazereeuw \& Yarina, 2017). Much like the Japanese machizukuri councils that facilitate communication between local residents and the government, design professions must also act as a mediator 
who is responsible for finding the most appropriate design interventions that respond to the specific needs of local residents. (Allan \& Bryant, 2011)

\subsection{0 | Education}

Understanding a space's functionality and ensuring that residents have the ability to independently use its features, both in daily life and during an emergency, are critical (Masuda, 2014). The education of the community through events and drills "further embed knowledge of the disaster functions of these parks" (Mazereeuw \& Yarina, 2017, p. 66). Within the context of evacuation routes, León \& March (2014) agree that evacuation drills and information campaigns would reinforce appropriate route choice during a disaster. As part of their design proposal for the Golden Gate Park sustainable infrastructure concept, CMG Landscape Architects suggested an annual overnight event called 'Camp the Park' to increase familiarity with the park infrastructure and boost general disaster preparedness (Public Architecture, 2013).

Villagra-Islas and Dobbie (2014) also address the potential to design open spaces that can alert users to various hazards in the landscape. Although the authors acknowledge that this area of research requires further study, they give the example of landscape elements that could "alert users to the instability of the land during an earthquake" (Villagra-Islas \& Dobbie, 2014, p. 678). Education is also a key component of DPP programming in Japan. The Tokyo Rinkai Disaster Prevention Park focuses on training and dissemination of information on disaster preparedness. The Park also houses a learning facility, which is both a tourist attraction and important education tool for local residents. The facility includes an immersive earthquake simulation that guides participants through the first 72 hours after an earthquake, and a learning centre with resources on disaster preparedness (The Tokyo Rinkai Disaster Prevention Park, n.d.-a, n.d.-b).

The results of the systematic review identified a range of themes from general guiding principles to site-specific interventions that address both the social and physical impacts of disaster. The following chapter considers each theme individually and explores some of the implications of the results for the design of public open space to support seismic resilience. 


\section{CHAPTER 5 | DISCUSSION}

The goal of this research was to explore how landscape architects can proactively plan and design public open space to support seismic resilience. This chapter considers the results of the systematic review in relation to the research goal and objectives. With the increasing interest in designing open spaces that can play a more active role in disaster response and recovery, there was a need to consolidate existing literature. The results of the systematic review identified ten key themes (summarized in Table 4): multifunctionality and embeddedness; resilience; networks and connectivity; distribution and grouping; location and suitability; size and function; site elements; programming; community engagement and education. These themes serve as a foundation for future development of more specific guidelines to direct planning and design of open space. The discussion section addresses each theme individually and reflects on their potential application.

Table 4: Systematic Review Key Themes

THEMES

1 Multifunctionality 8 Embeddedness

2 Resilience

3 Networks \& Connectivity

4 Distribution \& Grouping

5 Location \& Suitability

\section{KEY POINTS}

Design for multifunctionality (e.g., objects or functions that transform to serve different needs)

- Aim to embed disaster function and design into daily life

- Look for opportunities to align both disaster and normative design needs

- Use resilience attributes to guide normative design to ensure alignment with recovery planning

- Focus on the attributes of diversity, modularity, redundancy, and multi-scale connectivity

- Strengthening connections from vulnerable areas to safe open space should be prioritized

- $\quad$ Networks must function on multiple scales, from the regional to the neighbourhood.

- Boost functionality of open space by creating nodes with critical infrastructure and facilities, and/or cluster open spaces of different size and functions

- Consider both population density and risk exposure when locating open space

- Open space in areas of low risk must be designed to accommodate evacuees from high risk areas

- Weigh the benefits of locating open space in high risk vs. low risk areas

- Use scenario planning to determine the best areas for design interventions and inform design parameters

- Factors such as density of vegetation, accessibility, slope and sight lines should be considered when evaluating site suitability 
THEMES

6

Size \& Function

$7 \quad$ Site Elements

8 Programming

9 Community

Engagement

10 Education
KEY POINTS

- Plan for a range of open space sizes with diverse functions

- Consult humanitarian guidelines on minimum requirements for emergency shelter

- Ensure that basic humanitarian needs (water, sanitation, food) can be met within the open space

- Incorporate solar power generation

- Design lighting and way-finding elements to guide evacuees to open space

- Incorporate programing and features that encourage social interaction and build social capital

- Increase individual and community resilience through features that foster positive emotions (e.g., community gardens)

- Ensure that the local community is included in any disaster prevention planning or design projects

- Incorporate existing community organizations and infrastructure into plans

- Host events and drills in open spaces for seismic resilience to improve knowledge of open space function and increase general disaster preparedness

- Incorporate cues in the landscape that alert the community to possible hazards

\section{Multifunctionality and Embeddedness}

The concept of multifunctionality perhaps best encapsulates the underlying aim of public open space design for seismic resilience. Designing open space to perform multiple functions and transforming to accommodate different scenarios was well established in the results (e.g., León \& March, 2014; Villagra-Islas \& Dobbie, 2014). The role of multifunctionality is also addressed in seminal articles, such as Geis (2000), on design for disaster mitigation.

The challenge with implementing multifunctionality is finding a suitable alignment of function or places where functions can be embedded in design for daily use. The precedent set by the Golden Gate Park design concept is an effective illustration of the potential for multifunctionality and the alignment of both daily and emergency needs. While the concept was based on the Park's polo field, other open space typologies offer different opportunities to support disaster response and recovery. 
For example, parking lots (excluding multi-story parking structures) provide a flat open space that could be suitable to support evacuees in the aftermath of a disaster. Parking stall measurements could dovetail with humanitarian guidelines on per-person space requirements for establishing emergency shelter. In addition, with the wider adoption of electric vehicles, some parking stalls now include charging stations with solar panel roofs that could provide both power and shelter during response and recovery (e.g., Envision Solar, 2017).

\section{Resilience}

Allan and Bryant $(2011,2014)$ and Allan et al. (2013) discuss the use of resilience attributes to further guide alignment of needs. The resilience attributes of diversity, modularity, redundancy and connectivity should be the primary focus of actions to address the physical impacts of disaster. Using these attributes as a guide will help to ensure that alternative functions, systems and networks continue to operate even in the event of a major systems failure.

Although resilience attributes can be useful as general guiding principles, it is important to briefly acknowledge the ongoing debate on the concept of resilience. While resilience has become a leading focus of international policy and disaster risk-reduction strategies, at present there are very few frameworks that actually operationalize resilience (Sudmeier, Jaboyedoff, \& Jaquet, 2013). Others have noted "a profound lack of clarity on risk and resilience" (Mochizuki, Keating, Liu, Hochrainer-Stigler, \& Mechler, 2017, p. 1).

In the context of planning for hazards such as earthquakes it is less important to address specified resilience (e.g., focused on a specific hazard or problem), and more important to focus on general resilience. General resilience considers improvements to the whole system (Bryant \& Allan, 2015). Although the term seismic resilience has been used throughout the thesis, because earthquakes are a catalyst for a number of different secondary hazards, in a broad sense seismic resilience is much the same as general resilience.

\section{Networks \& Connectivity}

The systems of networks that connect open space operate on many different scales, from the regional to the neighbourhood. General improvements to the network should focus on enhancing connectivity on these multiple scales, as well as accessibility and qualitative improvements to the street network (e.g., Allan et al., 2013; Tumini et al., 2017). Priority should 
also be directed towards improving connections between areas with high levels of social or physical vulnerability and those of safe open space (León \& March, 2014).

Results from this section overlap with emergency management and evacuation planning, and reflect established principles in urban planning and design. The American Planning Association encourages planning for redundancy when designing street networks to ensure multiple entrance and exits in the event that certain streets are blocked during a disaster (e.g., Schwab, 2014). Of the ten themes discussed here, the design of networks has perhaps the most limited opportunities for modification. While it is conceptually important to understand relationships between scale, redundancy and connectivity, the feasibility of implementing changes are limited in well established urban forms.

\section{Distribution \& Grouping}

In addition to improving connectivity it is also important to consider boosting the functionality of open space by creating nodes with critical infrastructure and facilities, and/or clustering open spaces of different sizes and functions (Anhorn \& Khazai, 2015; Villagra et al., 2014). Returning to the parking lot example above, this type of open space is commonly associated with critical facilities such as hospitals. It is of course important to ensure that any buildings that border open space are either far enough away in the event of a building collapse, or designed in strict adherence to seismic building codes.

\section{Location and Suitability}

The location and suitability of areas that could support open space for seismic resilience must consider both population density and risk exposure. As Bahrainy (1998) notes, the need for public open space increases with the density of a population. However, in areas of low risk, open space should be designed to accommodate residents evacuating from areas of high risk (Tumini et al., 2017). Another consideration is whether to intentionally locate open space in areas that have been identified as hazardous, such as DPPs strategically positioned in tsunami inundation zones to provide vertical evacuation (Strusińska-Correia, 2017).

The process of determining location and suitability is connected to land use planning. Mileti (1999) describes land use planning as being among the most useful tools for hazard mitigation. Determining the placement of open space for seismic resilience should align with local land use 
plans and area hazard maps. Anhorn \& Khazai (2015), CMG Landscape Architecture (2017) and León \& March (2016) also employed various forms of scenario planning to determine the location and type of appropriate intervention. While scenario planning can be useful, Bryant \& Allan (2015) caution against its use in the context of general resilience, warning that it can place too much emphasis on a specific risk at the expense of considering the whole system.

The site conditions for suitability mentioned in the results were non-specific and referred to general characteristics such as density of vegetation, accessibility, slope and sight lines (León \& March, 2014; Turer Baskaya, 2015). The site inventory and analysis phase of a project should also assess soil type and hydrology for susceptibility of the site to liquefaction during an earthquake. Further, it is important to consider potential hazards associated with vegetation. Species that are highly flammable (e.g., Juniperus spp. and Taxus spp.) should be replaced with fire-resistant vegetation (FireSmart Canada, n.d.)

\section{Size \& Function}

Though shelter appears throughout the functions listed for disaster prevention parks in Japan (e.g., Masuda, 2014) it was unclear from the literature what form this shelter would take. Considering past disasters, it is likely that tents or temporary structure will be erected by emergency management agencies. However, this leaves a gap in the provision of shelter during the first 72 hours after a disaster. Returning to the concept of multifunctionality, many types of outdoor structures, such as pergolas, bandstands, gazebos or picnic shelters could be designed to function as an emergency shelter.

An additional consideration when planning shelter is seasonality. If an earthquake were to occur in winter, could these shelters be designed to provide some form of heating, or conversely cooling in the summer? In addition, attention should be paid to designing comfortable microclimates, considering elements such as wind, shade, orientation, and thermal properties of building materials (e.g., Brown, 2010; Middel, Häb, Brazel, Martin, \& Guhathakurta, 2014)

Though Japanese disaster prevention parks include a range of sizes, there appears to be increasing focus on smaller scale sites (Bryant \& Allan, 2013; Dionísio et al., 2012; Ishikawa, 2002). As mentioned above, large adjustments to networks may prove economically and logistically challenging. However, infusing a city's urban form with a greater amount of smaller open spaces could enhance the network without major modifications. Concentrating on 
improvements to open space on the neighbourhood or project scale may begin to create what Forman (1995) refers to as "stepping stones" (p. 136).

\section{Site Elements}

These stepping-stones of small open space should be designed to meet the basic needs of evacuees. While humanitarian standards such as The Sphere Project were mentioned in the context of calculating shelter size, these standards should also be consulted when planning other site elements. The Sphere Project provides guidance on four groups of minimum humanitarian standards for water, hygiene and sanitation; nutrition and food security; shelter and supplies; and health. Although the guidelines were intended for use by humanitarian organizations to guide appropriate response to disaster, they can also be applied to disaster preparedness activities (The Sphere Project, n.d.)

Of the basic humanitarian needs, water was both the most dominant element in the literature and perhaps the most straightforward to integrate into new or existing open space for seismic resilience. The results showed a range of possible options, from water supply tanks, manual water pumps, constructed streams, to ponds and water features (Bryant \& Allan, 2013; Ishikawa, 2002; Tokyo Metropolitan Government, n.d.).

The provision of food poses a greater design challenge. Although community gardens and edible plant species were addressed, the likelihood of either sustaining a population of evacuees is minimal, especially if an earthquake were to occur in the winter. At best these features would supplement food supplies. Flüchter (2003) briefly mentions that disaster prevention parks are required to have supply storehouses that contain food, yet it is unclear how these supplies are managed or accessed.

\section{Programming}

While providing basic physical necessities is critical, investing in open space programming builds social capital, ultimately contributing to community resilience. Incorporating programing and features that encourage social interaction should be a priority of open space design for seismic resilience. Although community gardens may not be a reliable source of food in a disaster scenario, they are an important buffer from stressful life events and facilitate the creation of support networks (Campbell et al., 2016; Chan et al., 2015;). 
Other opportunities to increase social capital should also be considered. For example, participation in sports programs and community initiatives have also been shown to be effective in generating social capital (Burnett, 2006; Pronyk et al., 2008). Dufferin Grove Park in Toronto, Canada, is a compelling example of effective open space programming. In addition to hosting a weekly farmers market, community dinners, and a range of arts events and performances, the park contains a variety of sports courts, play areas, community baking ovens, vegetable gardens and campfire pits.

\section{Community Engagement}

The importance of building social capital and increasing local self-sufficiency through community engagement also featured prominently in the literature (e.g., Masuda, 2014; Matsuda, 1990). Landscape architects who deal with projects in the public domain are well-versed in this type of participation (Juarez \& Brown, 2008). An additional benefit to smaller scale projects (as mentioned above) is the ability to work more closely with the community. However, it is important to consider that vulnerable groups who are likely to rely on open space after disaster may not necessarily be represented (Larsen, 2004). Efforts to include vulnerable populations in community-level planning for disaster resilience should be made a priority.

\section{Education}

This community engagement also needs to continue past initial park construction and become an ongoing feature in the form of education. An article from The Japan Times notes that a mother passing through a disaster prevention park was not aware of the emergency park features (Takaguchi, 2013). Without a continued education component, the utility of the open space may be undermined. The results suggest a range of education activities that could take place within open space to increase familiarity with park features, from training and drills to events and information campaigns (e.g., León \& March, 2014; Mazereeuw \& Yarina, 2017). Although ongoing organization of many of these activities remain outside of the domain of landscape architecture, they can be addressed directly in design proposals, as demonstrated by CMG Landscape Architects 'Camp the Park' event (Public Architecture, 2013). 
Many of the key themes address above are already well established in the design and planning fields. Where priorities for disaster mitigation and normative urban design diverge, opportunities can be found to integrate and align needs. Designing open space for seismic resilience will require input and guidance from a range of stakeholders. Landscape architects can coordinate and consolidate this array of different needs in order to create open space that contributes to building a culture of seismic resilience. 


\section{CHAPTER 6 | CONCLUSION}

This thesis contributes to developing a foundation for landscape architecture and allied design disciplines to better incorporate seismic resilience into the planning and design of public open spaces. Research on people's interactions with the post-disaster environment offers insight into the needs, uses and perceptions of open space after an earthquake. The disaster prevention park system in Japan, which evolved in response to a century of disturbances, established a precedent that helped guide the systematic review. The results from the 35 articles identified in the review provide a clearer picture of what open space for seismic resilience could look like.

According to the results, public open space for seismic resilience is:

- Multifunctional with disaster function embedded in design for daily use

- Guided by general attributes of resilience

- Connected by a redundant, accessible and legible multi-scale network

- Grouped to create nodes with critical infrastructure, facilities and other open spaces

- Located in relation to risk exposure and population density

- Composed of a range of site scales and functions

- A place where basic human needs can be met

- Programmed to create opportunities for social interaction and build social capital

- Designed with the community and local stakeholders

- A place for continued education and training in disaster preparedness

\section{1 | Limitations}

Despite the external interest in Japan's disaster prevention park system, there are few academic articles on the topic in English language publications. It is also evident from the database searches that a range of scholarship from China on disaster prevention parks exists. However, while Chinese journals provide a translation of the abstracts, no full text translation is available. Future research should include both Japanese and Chinese language articles to ensure that this source of scholarship is represented.

While conducting the systematic review, issues pertaining to the quality of academic literature did arise. Certain academic journal articles failed to cite direct quotes, did not cite any sources, or referenced questionable sources such as Wikipedia. Some of the sources returned in the 
database searches also had no clear methods, poor logic or unfounded assertions and were excluded from the systematic review.

For a thorough systematic review, typically a minimum of two reviewers are required to select articles for inclusion (Torgerson, 2003). However, this is perhaps more important in clinical medical reviews and not as much of a limiting factor with qualitative analysis of planning and design literature. In this particular area of study the use of a single reviewer should not diminish the accuracy of the results.

\section{2 | Future Research Directions}

If open space for seismic resilience is to function in both daily life and emergencies, it is important to address how these spaces will be used by different populations and regions with varying levels of development. Where there is a daily need for essentials such as food, water and shelter, it becomes difficult to justify only using this embedded infrastructure during a disaster. Determining how and if current disaster prevention parks in countries like Japan and China are used by populations, such as the homeless, should be addressed in future research. For example, is it permissible for benches to be used for cooking in daily park use? In addition, there is a gap in the literature evaluating the performance and effectiveness of disaster prevention parks. Future research should focus on how these spaces functioned during events like the 2011 Tōhoku earthquake and tsunami in Japan.

The implementation of design for disaster requires both guidelines to direct development and regulatory tools to ensure proper adherence to these guidelines. Certification programs like the Sustainable Sites Initiative (SITES), a national rating system that recognizes design and development of sustainable landscapes (ASLA, 2012), encourage "projects to design for scaled resiliency to other catastrophic natural events (e.g., flooding, earthquakes, drought, hurricanes, tornadoes) and encourages projects to apply for Innovation [credit] C10.1" (Green Business Certification Inc., 2014, p. 53). According to SITES, no projects have been submitted that have applied for a C10.1 credit incorporating design for earthquakes (Evans, 2016). Further development of guidelines on seismic resilience and open space could encourage the development of projects that begin to address this hazard. 


\section{3 | Concluding Remarks}

With the global threat of more catastrophic earthquakes looming in the near future, there is increasing urgency to create or fortify existing open space to support response and recovery efforts. In Canada, a significant earthquake will likely be the country's "greatest potential natural disaster" (CSRN, 2009). At present, the Cascadia Subduction Zone that runs from Vancouver Island to northern California poses a very real danger and has the potential to generate an earthquake measuring over magnitude 9.0 (Government of Canada, 2016b).

In the City of Vancouver, B.C., over half of the buildings were constructed before the introduction of seismic building codes (Hoekstra, 2016). As there have been no major earthquakes in Vancouver's recent history, "all the vulnerable buildings remain" (City of Vancouver, 2013, p. 42). Open space will play a critical role in the response and recovery of affected regions in the Province. What residents find when they arrive in these spaces will depend on the integration and alignment of daily and emergency needs and a collective willingness to pro-actively mitigate hazards, instead of reacting to the aftermath of disaster. 


\section{REFERENCES}

AFP news agency. (2017, February 12). Aftershocks rock survivors in Mindanao's Surigao. Retrieved February 14, 2017, from http://www.aljazeera.com/news/2017/02/aftershocksrock-survivors-mindanao-surigao-170212073533316.html

Ahern, J. (2011). From fail-safe to safe-to-fail: Sustainability and resilience in the new urban world. Landscape and Urban Planning, 100(4), 341-343. https://doi.org/10.1016/j.landurbplan.2011.02.021

Ainuddin, S., \& Routray, J. K. (2012). Community resilience framework for an earthquake prone area in Baluchistan. International Journal of Disaster Risk Reduction, 2, 25-36. https://doi.org/10.1016/j.ijdrr.2012.07.003

Al Jazeera News. (2016, October 27). Central Italy rocked by two earthquakes. Retrieved February 14, 2017, from http://www.aljazeera.com/news/2016/10/central-italy-rockedearthquakes-161027035725850.html

Alexander, D. E. (2002). Principles of Emergency Planning and Management. Oxford University Press.

Allan, P., \& Bryant, M. (2010). The Critical Role of Open Space in Earthquake Recovery: A Case Study. In Proceedings of the New Zealand Society of Earthquake Engineering Conference. Retrieved from http://db.nzsee.org.nz/2010/Paper34.pdf

Allan, P., \& Bryant, M. (2011). Resilience as a framework for urbanism and recovery. Journal of Landscape Architecture, 6(2), 34-45. https://doi.org/10.1080/18626033.2011.9723453

Allan, P., \& Bryant, M. (2014). The attributes of resilience: A tool in the evaluation and design of earthquake-prone cities. International Journal of Disaster Resilience in the Built Environment, 5(2), 109-129. https://doi.org/10.1108/IJDRBE-05-2012-0013

Allan, P., Bryant, M., Wirsching, C., Garcia, D., \& Teresa Rodriguez, M. (2013). The Influence of Urban Morphology on the Resilience of Cities Following an Earthquake. Journal of Urban Design, 18(2), 242-262. https://doi.org/10.1080/13574809.2013.772881

Allen, R. M., Gasparini, P., Kamigaichi, O., \& Bose, M. (2009). The Status of Earthquake Early Warning around the World: An Introductory Overview. Seismological Research Letters, 80(5), 682-693. https://doi.org/10.1785/gssrl.80.5.682

Amaratunga, D., \& Haigh, R. (Eds.). (2011). Post-Disaster Reconstruction of the Built Environment: Rebuilding for Resilience. Oxford, UK: Wiley-Blackwell. Retrieved from http://doi.wiley.com/10.1002/9781444344943

Ambraseys, N., \& Bilham, R. (2011). Corruption kills: On the anniversary of Haiti's devastating quake, Nicholas Ambraseys and Roger Bilham calculate that $83 \%$ of all deaths from building collapse in earthquakes over the past 30 years occurred in countries that are anomalously corrupt. Nature, 469(7329), 153+. 
American Red Cross. (2011a, December 31). Non-Traditional Shelter Case Studies. Retrieved from http://www.nationalmasscarestrategy.org/wp-content/uploads/2014/07/full-casestudies-final-29dec2011.pdf

American Red Cross. (2011b, December 31). Non-Traditional Shelter Concept of Operations Template. Retrieved from http://www.nationalmasscarestrategy.org/wpcontent/uploads/2014/07/non-traditional-shelter-concept-of-operations-template-final29dec2011.pdf

Amos, C. B., Audet, P., Hammond, W. C., Bürgmann, R., Johanson, I. A., \& Blewitt, G. (2014). Uplift and seismicity driven by groundwater depletion in central California. Nature, 509(7501), 483-486. https://doi.org/10.1038/nature13275

Andrea Henderson. (2006). The Human Geography of Catastrophe: Family Bonds, Community Ties, and Disaster Relief After the 1906 San Francisco Earthquake and Fire. Southern California Quarterly, (1), 37.

Anhorn, J., \& Khazai, B. (2015). Open space suitability analysis for emergency shelter after an earthquake. Natural Hazards and Earth System Science, 15(4), 789-803. https://doi.org/10.5194/nhess-15-789-2015

ASLA. (2012, September 17). National Sustainability Rating System Certifies Eight Landscape Projects. Retrieved January 19, 2017, from https://www.asla.org/NewsReleaseDetails.aspx?id=37456

Australian Government. (2014, May 15). What causes Tsunamis? Retrieved September 14, 2017, from http://www.ga.gov.au/scientific-topics/hazards/tsunami/basics/causes

Bahrainy, H. (1998). Urban Planning and Design in a Seismic-Prone Region (The Case of Rasht in Northern Iran). Journal of Urban Planning and Development, 124(4), 148-181. https://doi.org/10.1061/(ASCE)0733-9488(1998)124:4(148)

Bao, Z., \& Chen, B. (2004). Construction of urban green space system and reduction and prevention of urban disaster. Journal of Natural Disasters. Retrieved from http://en.cnki.com.cn/Article_en/CJFDTOTAL-ZRZH200402028.htm

Beijing Government. (2001). Measures of Beijing Municipality for the Implementation of the Law of the People's Republic of China on Protecting against and Mitigating Earthquake Disasters. Retrieved February 20, 2017, from http://www.ebeijing.gov.cn/feature_2/RegulationsRules/Regulations/t1125709.htm

Bellegarde-Smith, P. (2011). A Man-Made Disaster: The Earthquake of January 12, 2010—A Haitian Perspective. Journal of Black Studies, 42(2), 264-275.

Bowring, J., \& Swaffield, S. (2013). Shifting Landscapes: In Between Times. Harvard Design Magazine, (36), 2-11. 
Brand, D., \& Nicholson, H. (2016). Public space and recovery: learning from post-earthquake Christchurch. Journal of Urban Design, 21(2), 159-176.

https://doi.org/10.1080/13574809.2015.1133231

Breivold, H. P., Crnkovic, I., \& Larsson, M. (2012). A systematic review of software architecture evolution research. Information and Software Technology, 54(1), 16-40.

https://doi.org/10.1016/j.infsof.2011.06.002

Brown, R. (2010). Design with microclimate: the secret to comfortable outdoor spaces.

Washington: Island Press. Retrieved from

http://public.eblib.com/choice/publicfullrecord.aspx?p=3317501

Brown, R. D., \& Corry, R. C. (2011). Evidence-based landscape architecture: The maturing of a profession. Landscape and Urban Planning, 100(4), 327-329.

https://doi.org/10.1016/j.landurbplan.2011.01.017

Bruneau, M., Chang, S. E., Eguchi, R. T., Lee, G. C., O’Rourke, T. D., Reinhorn, A. M., ... von Winterfeldt, D. (2003). A Framework to Quantitatively Assess and Enhance the Seismic Resilience of Communities. Earthquake Spectra, 19(4), 733-752.

https://doi.org/10.1193/1.1623497

Bryant, M., \& Allan, P. (2013). Open Space Innovation in Earthquake Affected Cities. In J. Tiefenbacher (Ed.), Approaches to Disaster Management - Examining the Implications of Hazards, Emergencies and Disasters. InTech. https://doi.org/10.5772/55465

Bryant, M., \& Allan, P. (2015). Designing Regional Resilience. Presented at the NZSEE Annual Technical Conference. Retrieved from http://www.nzsee.org.nz/db/2015/Papers/l02_Allan.pdf

Burnett, C. (2006). Building Social Capital Through an 'Active Community Club'. International Review for the Sociology of Sport, 41(3-4), 283-294.

https://doi.org/10.1177/1012690207078381

Campbell, L. K., Svendsen, E. S., Sonti, N. F., \& Johnson, M. L. (2016). A social assessment of urban parkland: Analyzing park use and meaning to inform management and resilience planning. Environmental Science \& Policy, 62, 34-44.

https://doi.org/10.1016/j.envsci.2016.01.014

Celik, A., \& Erduran, F. (2011). Determination of earthquake park facilities in Kocaeli. African Journal of Agricultural Research, 6(24), 5558-5566. https://doi.org/10.5897/AJAR10.944

Centers for Disease Control and Prevention. (2014, January 23). During an Earthquake: Outdoor Safety. Retrieved October 2, 2017, from https://www.cdc.gov/disasters/earthquakes/outdoorsafety.html

Chan, J., DuBois, B., \& Tidball, K. G. (2015). Refuges of local resilience: Community gardens in post-Sandy New York City. Urban Forestry \& Urban Greening, 14(3), 625-635. https://doi.org/10.1016/j.ufug.2015.06.005 
Childers, D., Cadenasso, M., Grove, J., Marshall, V., McGrath, B., \& Pickett, S. (2015). An Ecology for Cities: A Transformational Nexus of Design and Ecology to Advance Climate Change Resilience and Urban Sustainability. Sustainability, 7(4), 3774-3791. https://doi.org/10.3390/su7043774

China Daily. (2004, February 2). Emergency shelters planned for Beijing residents. Retrieved March 7, 2017, from http://www.chinadaily.com.cn/en/doc/200402/02/content_302150.htm

City of Vancouver. (2013). Earthquake Preparedness Strategy Update. Retrieved from http://vancouver.ca/files/cov/Earthquake-Preparedness-Strategy-20131203.pdf

City of Vancouver. (2017, March 1). Disaster support hubs. Retrieved April 3, 2017, from http://vancouver.ca/home-property-development/disaster-support-hubs.aspx

Clancey, G. K. (2006). Earthquake nation: the cultural politics of Japanese seismicity, 18681930. Berkeley: University of California Press.

CMG Landscape Architecture. (2017). Resilient SF. Retrieved October 23, 2017, from https://www.cmgsite.com/project/resilient-sf/

Copley, N., Bowring, J., \& Abbott, M. (2015). Thinking ahead: design-directed research in a city which experienced fifty years of sea level change overnight. Journal of Landscape Architecture, 10(2), 70-81. https://doi.org/10.1080/18626033.2015.1058577

CSRN. (2009). Why a Seismic Research Network? Retrieved November 23, 2017, from http://csrn.mcgill.ca/main.html

Cubrinovski, M., Bray, J. D., Taylor, M., Giorgini, S., Bradley, B., Wotherspoon, L., \& Zupan, J. (2011). Soil Liquefaction Effects in the Central Business District during the February 2011 Christchurch Earthquake. Seismological Research Letters, 82(6), 893-904. https://doi.org/10.1785/gssrl.82.6.893

Cutter, S. L., Boruff, B. J., \& Shirley, W. L. (2003). Social Vulnerability to Environmental Hazards. Social Science Quarterly, 84(2), 242-261. https://doi.org/10.1111/15406237.8402002

Cyranoski, D. (2011). Japan faces up to failure of its earthquake preparations. Nature News, 471(7340), 556-557. https://doi.org/10.1038/471556a

Daniell, J. (2013, May 9). Sichuan 2008: A disaster on an immense scale. BBC News. Retrieved from http://www.bbc.co.uk/news/science-environment-22398684

Daniell, J. E., Schaefer, A. M., \& Wenzel, F. (2017). Losses Associated with Secondary Effects in Earthquakes. Frontiers in Built Environment, 3. Retrieved from https://doajorg.subzero.lib.uoguelph.ca 
Department of Homeland Security. (2007, March 30). Disaster Planning Is Up To You. Retrieved September 5, 2017, from https://www.fema.gov/newsrelease/2007/03/30/disaster-planning-you

Department of Homeland Security. (n.d.). Earthquakes. Retrieved April 6, 2017, from https://www.ready.gov/earthquakes

Dionísio, M. R., Candeia de Souza, M. C., \& Ota, H. (2012). The Importance of Public Space for Sustainable Urban Rehabilitation. The International Journal of the Constructed Environment, 1(4), 39-50. https://doi.org/10.18848/2154-8587/CGP/v01i04/37500

Dionisio, M. R., Kingham, S., Banwell, K., \& Neville, J. (2016). Geospatial tools for Community Engagement in the Christchurch Rebuild, New Zealand. Sustainable Cities and Society, 27, 233-243. https://doi.org/10.1016/j.scs.2016.04.007

Dobbie, M., \& Green, R. (2013). Public perceptions of freshwater wetlands in Victoria, Australia. Landscape and Urban Planning, 110, 143-154. https://doi.org/10.1016/j.landurbplan.2012.11.003

Edgington, D. W. (2010). Reconstructing Kobe: the geography of crisis and opportunity. Vancouver: UBC Press.

Edgington, D. W. (2016). Reflections on the Hanshin Earthquake of 1995 and the Reconstruction of Kobe, Japan. In P. Daly \& R. M. Feener (Eds.), Rebuilding Asia Following Natural Disasters (pp. 108-140). Cambridge: Cambridge University Press. https://doi.org/10.1017/CBO9781139683548.005

Ekstrom, G. (2006). Seasonality and Increasing Frequency of Greenland Glacial Earthquakes. Science, 311(5768), 1756-1758. https://doi.org/10.1126/science.1122112

Elwood, K. J. (2013). Performance of concrete buildings in the 22 February 2011 Christchurch earthquake and implications for Canadian codes. Canadian Journal of Civil Engineering, 40(8), 759-776. https://doi.org/10.1139/cjce-2011-0564

Emergency Management BC, \& British Columbia. Ministry of Justice. (2015, July 20). B.C. Earthquake Immediate Response Plan. Victoria, British Columbia : Emergency Management BC.

Envision Solar. (2017). EV ARC ${ }^{\mathrm{TM}}$ - Electric Vehicle Autonomous Renewable Charger | Envision Solar. Retrieved November 19, 2017, from http://www.envisionsolar.com/evarcl

Evans, M. (2016, December 11). Case 01423049 : SITES Contact Form Submission [ ref:_00D409UeD._50040rNCDv:ref ].

Evans, N. (2002). Machi-zukuri as a new paradigm in Japanese urban planning: reality or myth? Japan Forum, 14(3), 443-464. https://doi.org/10.1080/0955580022000008745 
Fan, L., Xue, S., \& Liu, G. (2012). Patterns and its disaster shelter of urban green space: Empirical evidence from Jiaozuo city, China. African Journal Of Agricultural Research, 7(7). https://doi.org/10.5897/AJAR11.1661

Fang, D. (2011). Research Progress of Domestic Urban Green Space Planning in Disasterprevention during 2001-2010. Journal of Anhui Agricultural Sciences, 25. Retrieved from http://en.cnki.com.cn/Article_en/CJFDTOTAL-AHNY201125065.htm

Fei, X., \& Yu, S. (2010). Strategy and Study of Disaster Prevention Park in Townships. (S. Wang, W. J. Ammann, Y. Shao, Y. Shi, \& C. Sutter, Eds.) (Vol. 1). Harbin: Harbin Inst Technology, P R China.

FireSmart Canada. (n.d.). FireSmart Guide to Landscaping. Partners in Protection. Retrieved from https://www.firesmartcanada.ca/images/uploads/resources/FireSmart-Guide-toLanscaping.pdf

First, J. M., First, N. L., \& Houston, J. B. (2017). Intimate Partner Violence and Disasters: A Framework for Empowering Women Experiencing Violence in Disaster Settings. Affilia: Journal of Women and Social Work, 32(3), 390-403. https://doi.org/10.1177/0886109917706338

Flüchter, W. (2003). Tokyo before the Next Earthquake: Agglomeration-Related Risks, Town Planning and Disaster Prevention. The Town Planning Review, 74(2), 213-238. https://doi.org/10.2307/40112553

Forman, R. T. T. (1995). Some general principles of landscape and regional ecology. Landscape Ecology, 10(3), 133-142. https://doi.org/10.1007/BF00133027

Frigerio, I., Ventura, S., Strigaro, D., Mattavelli, M., De Amicis, M., Mugnano, S., \& Boffi, M. (2016). A GIS-based approach to identify the spatial variability of social vulnerability to seismic hazard in Italy. Applied Geography, 74(Complete), 12-22. https://doi.org/10.1016/j.apgeog.2016.06.014

Galloway, B., Hare, J., Brunsdon, D., Wood, P., Lizundia, B., \& Stannard, M. (2014). Lessons from the Post-Earthquake Evaluation of Damaged Buildings in Christchurch. Earthquake Spectra, 30(1), 451-474. https://doi.org/10.1193/022813EQS057M

Gap Filler. (n.d.). About Gap Filler. Retrieved June 15, 2017, from http://gapfiller.org.nz/about/

Geis, D. E. (2000). By Design: The Disaster Resistant and Quality-of-Life Community. Natural Hazards Review, 1(3), 151-160. https://doi.org/10.1061/(ASCE)15276988(2000)1:3(151)

Gobster, P. H., Nassauer, J. I., Daniel, T. C., \& Fry, G. (2007). The shared landscape: what does aesthetics have to do with ecology? Landscape Ecology, 22(7), 959-972. https://doi.org/10.1007/s10980-007-9110-x

Godschalk, D. R. (2003). Urban Hazard Mitigation: Creating Resilient Cities. Natural Hazards Review, 4(3), 136-143. https://doi.org/10.1061/(ASCE)1527-6988(2003)4:3(136) 
Government of Canada. (2015, January 15). Earthquakes. Retrieved May 23, 2017, from https://www.getprepared.gc.ca/cnt/hzd/rthqks-en.aspx

Government of Canada. (2016a). Emergency Management Planning. Retrieved October 2, 2017, from https://www.publicsafety.gc.ca/cnt/mrgnc-mngmnt/mrgnc-prprdnss/mrgncmngmnt-plnnng-en.aspx

Government of Canada. (2016b). Seismic zones in Western Canada. Retrieved November 24, 2017, from http://www.earthquakescanada.nrcan.gc.ca//zones/westcan-en.php

Government of Nepal, \& International Organization for Migration. (2011, November 21). Report On Identification Of Open Spaces For Humanitarian Purposes In Kathmandu Valley. Retrieved from http://un.org.np/sites/default/files/2011-11-21--Open-SpaceHumanitarian-Purpose.pdf

Green Business Certification Inc. (2014). SITES v2 Rating System For Sustainable Land Design and Development.

Greening the Rubble. (n.d.-a). Coffee Zone. Retrieved June 21, 2017, from http://greeningtherubble.org.nz/our-projects/coffee-zone/

Greening the Rubble. (n.d.-b). Home. Retrieved June 21, 2017, from http://greeningtherubble.org.nz/

Griffiths, R. (2004). Knowledge production and the research-teaching nexus: the case of the built environment disciplines. Studies in Higher Education, 29(6), 709-726. https://doi.org/10.1080/0307507042000287212

Gülgün, B., Yazici, K., Dursun, S., \& Türkyılmaz Tahta, B. (2016). Earthquake Park Design and Some Examples from the World and Turkey. Journal of International Environmental Application \& Science, 11(2), 159-165.

Guo, M., \& Liu, X. (2006). Constructing Calamity-Proof Cities with "Flexible Structures":Reflection on the Construction of Urban Calamity-Preventive Green Space Based on the Lessons Learned from Bam Earthquake. Journal of Beijing Forestry University.

Haddaway, N. R., \& Bayliss, H. R. (2015). Shades of grey: Two forms of grey literature important for reviews in conservation. Biological Conservation, 191, 827-829. https://doi.org/10.1016/j.biocon.2015.08.018

Haddow, G. D., Bullock, J. A., \& Coppola, D. P. (2014). Introduction to emergency management. Retrieved from https://www.overdrive.com/search?q=D9510657-5DDF40B0-80BF-FED583FF3E96

Harville, E. W., Taylor, C. A., Tesfai, H., Xu Xiong, \& Buekens, P. (2011). Experience of Hurricane Katrina and Reported Intimate Partner Violence. Journal of Interpersonal Violence, 26(4), 833-845. https://doi.org/10.1177/0886260510365861 
Havens, T. R. H. (2011). Parkscapes: green spaces in modern Japan. Honolulu: University of Hawai'i Press.

Hein, C. (2002). Toshikeikaku and Machizukuri in Japanese Urban Planning. Japanstudien, 13(1), 221-252. https://doi.org/10.1080/09386491.2002.11826881

Higgins, J., \& Green, S. (Eds.). (2011). Cochrane Handbook for Systematic Reviews of Interventions Version 5.1.0. The Cochrane Collaboration. Retrieved from http://handbook-5-1.cochrane.org/

Hoekstra, G. (2016, October 30). B.C. earthquake threatens Vancouver buildings. Retrieved May 21, 2017, from http://theprovince.com/feature/b-c-earthquake-threatens-vancouverbuildings

Hong, L., Hu, X., Chen, C., Wang, Y., \& Xiao, S. (2010). Study about Planning of Urban Disaster-prevention Green Space. Northern Horticulture.

Hong, W., \& Guo, R. (2017). Indicators for quantitative evaluation of the social services function of urban greenbelt systems: A case study of shenzhen, China. Ecological Indicators, 75, 259-267. https://doi.org/10.1016/j.ecolind.2016.12.044

Howard, R. (2012, February 9). New Zealand: Collapsed Building Was Substandard. Wall Street Journal. Retrieved from https://search-proquest-

com.subzero.lib.uoguelph.ca/docview/920347791/fulltext/CF405EE82CCB483EPQ/1?ac countid=11233

Huang, H.-P., \& Chu, T.-J. (2016). Experience of Planning the Local Climate Change Adaptation Plan in Taoyuan. Journal of Civil Engineering and Architecture, 10(3). https://doi.org/10.17265/1934-7359/2016.03.005

Hunter, J. (2016, January). Earthquakes in Japan\&lt;a href=\&quot;\#afn1\&quot;\&gt;*\&lt;/a\&gt; Retrieved March 26, 2017, from /core/journals/modern-asian-studies/article/divclasstitleearthquakes-in-japana-hrefafn1-reftypefnadiv/5621BD92A7D9730E398B00ACFE6E1FE1

Ibes, D. C. (2008). Post-disaster Parks: Prospects, Problems, and Prescriptions. Texas State University - San Marcos. Retrieved from https://digital.library.txstate.edu/handle/10877/3365

Ishikawa, M. (2002). Landscape planning for a safe city. Annals of Geophysics, 45(6). https://doi.org/10.4401/ag-3544

Jang, N., Li, G., Zheng, X., \& Zhang, Z. (2004). Lessons of Urban Disaster Prevention from Japanese Experience - A Case of Urban Park. World Regional Studies. Retrieved from http://en.cnki.com.cn/Article_en/CJFDTOTAL-SJDJ200404006.htm 
Jayakody, R. R. J. ., Amarathunga, D., \& Haigh, R. (2016). The use of Public Open Spaces for Disaster Resilient Urban Cities. Presented at the 12th International Conference of the International Institute for Infrastructure Resilience and Reconstruction, Sri Lanka. Retrieved from https://www.researchgate.net/publication/305999867_The_use_of_Public_Open_Space s_for_Disaster_Resilient_Cities

Jia, J., Liu, D., Tang, J., Wu, W., \& Zhao, S. (2008). Lack Of Urban Disaster Prevention Land And Disaster Prevention Green Field Construction: From Perspective Of Wenchuan Earthquake. City Planning Review. Retrieved from http://en.cnki.com.cn/Article_en/CJFDTOTAL-CSGH200807009.htm

Jiang, J., Shi, J., \& Li, Y. (2008). The Planning and Construction of City Parks from the Perspective of Disaster Prevention and Reduction:A Case Study of Chengdu City. Journal of Southwest Jiaotong University. Retrieved from http://en.cnki.com.cn/Article_en/CJFDTOTAL-XNJS200805017.htm

Jones, S., \& Agren, D. (2017, September 9). Mexico earthquake kills at least 61 and sparks mass evacuations. Retrieved September 13, 2017, from https://www.theguardian.com/world/2017/sep/08/mexico-earthquake-warning-tsunami

Journeay, J. M., Dercole, F., Mason, D., Westin, M., Prieto, J. A., Wagner, C. L., ... Ventura, C. E. (2015). A profile of earthquake risk for the District of North Vancouver, British Columbia (No. 7677) (p. 224). Geological Survey of Canada. Retrieved from https://doi.org/10.4095/296256

Juarez, J. A., \& Brown, K. D. (2008). Extracting or Empowering?: A Critique of Participatory Methods for Marginalized Populations. Landscape Journal, 27(2), 190-204. https://doi.org/10.3368/lj.27.2.190

Kaiser, A., Holden, C., Beavan, J., Beetham, D., Benites, R., Celentano, A., ... Zhao, J. (2012). The Mw 6.2 Christchurch earthquake of February 2011: preliminary report. New Zealand Journal of Geology and Geophysics, 55(1), 67-90. https://doi.org/10.1080/00288306.2011.641182

Kaplan, R., Kaplan, S., \& Brown, T. (1989). Environmental Preference: A Comparison of Four Domains of Predictors. Environment and Behavior, 21(5), 509-530. https://doi.org/10.1177/0013916589215001

Kilic, C., \& Ulusoy, M. (2003). Psychological effects of the November 1999 earthquake in Turkey: an epidemiological study. Acta Psychiatrica Scandinavica, 108(3), 232-238. https://doi.org/10.1034/j.1600-0447.2003.00119.x

Kim, K., \& Olshansky, R. B. (2014). The Theory and Practice of Building Back Better. Journal of the American Planning Association, 80(4), 289-292. https://doi.org/10.1080/01944363.2014.988597

Kobayashi, I. (2007). Machizukuri (Community Development) for Recovery Whose Leading Role Citizens Play. Journal of Disaster Research, 2(5), 359-371.

https://doi.org/10.20965/jdr.2007.p0359 
Kohn, S., Eaton, J. L., Feroz, S., Bainbridge, A. A., Hoolachan, J., \& Barnett, D. J. (2012). Personal Disaster Preparedness: An Integrative Review of the Literature. Disaster Medicine and Public Health Preparedness, 6(3), 217-231.

Kumagai, Y., Gibson, R. B., \& Filion, P. (2015). Evaluating long-term urban resilience through an examination of the history of green spaces in Tokyo. Local Environment, 20(9), 1018-1039. https://doi.org/10.1080/13549839.2014.887060

Kusakabe, E. (2013). Advancing sustainable development at the local level: The case of machizukuri in Japanese cities. Progress in Planning, 80, 1-65. https://doi.org/10.1016/j.progress.2012.06.001

Larsen, L. (2004). Bonding and Bridging. Journal of Planning Education and Research, 24(1), 64-77.

Lauve-Moon, K., \& Ferreira, R. J. (2017). An Exploratory Investigation: Post-disaster Predictors of Intimate Partner Violence. Clinical Social Work Journal, 45(2), 124-135. https://doi.org/10.1007/s10615-015-0572-z

León, J., \& March, A. (2014). Urban morphology as a tool for supporting tsunami rapid resilience: A case study of Talcahuano, Chile. Habitat International, 43, 250-262. https://doi.org/10.1016/j.habitatint.2014.04.006

León, J., \& March, A. (2016). An urban form response to disaster vulnerability: Improving tsunami evacuation in Iquique, Chile. Environment and Planning B: Planning and Design, 43(5), 826-847. https://doi.org/10.1177/0265813515597229

Li, H., Zhao, L., Huang, R., \& Hu, Q. (2017). Hierarchical earthquake shelter planning in urban areas: A case for Shanghai in China. International Journal of Disaster Risk Reduction, 22, 431-446. https://doi.org/10.1016/j.ijdrr.2017.01.007

Li, J., \& Xia, J. (2007). Study of Urban Disaster Prevention Park Planning. Chinese Landscape Architecture.

$\mathrm{Li}, \mathrm{S}$. (2014). The development of disaster prevention green space in China. Landscape Architecture Frontiers, 2(4), 44+.

Li, W., \& Zhang, L. (2010). The Layout Study on the Disaster-prevention Functions of Green Space of Harbin City Parks. Northern Horticulture. Retrieved from http://en.cnki.com.cn/Article_en/CJFDTOTAL-BFYY201012047.htm

Liu, L., Lin, Y., \& Wang, S. (2014). Urban design for post-earthquake reconstruction: A case study of Wenchuan County, China. Habitat International, 41, 290-299. https://doi.org/10.1016/j.habitatint.2013.09.001 
Lowe, S. S., \& Fothergill, A. (2003). A Need to Help: Emergent Volunteer Behavior after 9/11. American Sociological Association, Atlanta Hilton Hotel, Atlanta, GA. Retrieved from https://www.researchgate.net/profile/Alice_Fothergill/publication/228551729_A_Need_to _Help_Emergent_Volunteer_Behavior_after_September_11th/links/557054c6 $\bar{c} 6 \mathbf{8}$ aeab $\overline{7} 7$ 7228c13f.pdf

Lu, X., Xue, Z., \& Zhao, Z. (2006). The Plan Research of Disaster-proof Parks. Journal of Hebei Institute of Technology.

Lucini, B. (2014). Populations' Experience of Earthquakes and Possible Resilient Responses to Disasters. In B. Lucini, Disaster Resilience from a Sociological Perspective (pp. 155188). Cham: Springer International Publishing. https://doi.org/10.1007/978-3-319-04738$6 \_8$

Madianos, M. G., \& Evi, K. (2010). Trauma and Natural Disaster: The Case of Earthquakes in Greece. Journal of Loss and Trauma, 15(2), 138-150.

https://doi.org/10.1080/15325020903373185

Marcus, C. C., \& Sachs, N. A. (2014). Therapeutic landscapes: an evidence-based approach to designing healing gardens and restorative outdoor spaces. Hoboken, New Jersey: Wiley.

Masterson, J. H., Peacock, W. G., Zandt, S. S. V., Grover, H., Schwarz, L. F., \& Cooper, J. T. (2014). Planning for community resilience: a handbook for reducing vulnerability to disasters. Retrieved from

http://search.ebscohost.com/login.aspx?direct=true\&scope=site\&db=nlebk\&db=nlabk\&A $\mathrm{N}=880969$

Masuda, N. (2014). Disaster refuge and relief urban park system in Japan. Landscape Architecture Frontiers, 2(4), 52+.

Matsuda, I. (1990). Natural Disasters and Countermeasures for the Tokyo Lowland. Geographical Review of Japan, Series B., 63(1), 108-119. https://doi.org/10.4157/grj1984b.63.108

Mazereeuw, M. (2015). In conversation with Miho Mazereeuw. Journal of Landscape Architecture, 10(1), 36-37. https://doi.org/10.1080/18626033.2015.1011440

Mazereeuw, M., \& Yarina, E. (2017). Emergency Preparedness Hub: Designing Decentralized Systems for Disaster Resilience. Journal of Architectural Education, 71(1), 65-72. https://doi.org/10.1080/10464883.2017.1260928

Mclntyre, L. (2013). The Sandy Squad: Landscape Architects Deploy to Help Rebuild New York City's Parks After Hurricane Sandy. Landscape Architecture Magazine, 103(11).

Mckean, C. A. (2014, August 19). Tokyo's disaster parks: hi-tech survival bunkers hidden under green spaces. The Guardian. Retrieved from https://www.theguardian.com/cities/2014/aug/19/tokyo-disaster-parks-hi-tech-survivalbunkers-hidden-green-spaces-earthquake 
Michael, A. (n.d.). What was the duration of the earthquake? Why don't you report the duration of each earthquake? How does the duration affect the magnitude? Retrieved October 2, 2017, from https://www.usgs.gov/faqs/what-was-duration-earthquake-why-dont-youreport-duration-each-earthquake-how-does-duration?qt-news_science_products=7\#qtnews_science_products

Middel, A., Häb, K., Brazel, A. J., Martin, C. A., \& Guhathakurta, S. (2014). Impact of urban form and design on mid-afternoon microclimate in Phoenix Local Climate Zones. Landscape and Urban Planning, 122, 16-28. https://doi.org/10.1016/j.landurbplan.2013.11.004

Mileti, D. (1999). Disasters by Design: A Reassessment of Natural Hazards in the United States. Joseph Henry Press.

Mochizuki, J., Keating, A., Liu, W., Hochrainer-Stigler, S., \& Mechler, R. (2017). An overdue alignment of risk and resilience? A conceptual contribution to community resilience. Disasters. https://doi.org/10.1111/disa.12239

Montejano-Castillo, M., \& Moreno-Villanueva, M. (2016). The adaptability of public space in Mexico City after an earthquake: a preliminary classification. International Journal of Safety and Security Engineering, 6(2), 104-113. https://doi.org/10.2495/SAFE-V6-N2104-113

Montgomery, R. (2012). Greening the Rubble in Christchurch: civic ecological reclamation efforts during a crisis event. Retrieved from

https://researcharchive.lincoln.ac.nz/handle/10182/4409

Montgomery, R., Wesener, A., \& Davies, F. (2016). Bottom-up Governance after a Natural Disaster: A Temporary Post-Earthquake Community Garden in Central Christchurch, New Zealand. Nordic Journal of Architectural Research, 28(3). Retrieved from http://arkitekturforskning.net/na/article/view/858

Municipality of Anchorage. (n.d.). Earthquake Park. Retrieved from http://www.muni.org/departments/parks/pages/earthquake\%20park.pdf

Murao, O. (2008). Case Study Of Architecture And Urban Design On The Disaster Life Cycle In Japan. Presented at the The 14th World Conference on Earthquake Engineering, Beijing, China. Retrieved from http://www.iitk.ac.in/nicee/wcee/article/14_S08-032.PDF

National Park Service. (n.d.1). 1906 Earthquake and the Army - Presidio of San Francisco (U.S. National Park Service). Retrieved January 13, 2017, from https://www.nps.gov/prsf/learn/historyculture/1906-earthquake.htm

National Park Service. (n.d.2). 1906 Earthquake: Refugee Camps - Presidio of San Francisco (U.S. National Park Service). Retrieved January 13, 2017, from https://www.nps.gov/prsf/learn/historyculture/1906-earthquake-relief-efforts-livingaccommodations.htm 
Nutsford, D., Pearson, A. L., \& Kingham, S. (2013). An ecological study investigating the association between access to urban green space and mental health. Public Health, 127(11), 1005-1011. https://doi.org/10.1016/j.puhe.2013.08.016

Okvat, H. A., \& Zautra, A. J. (2014). Sowing Seeds of Resilience: Community Gardening in a Post-Disaster Context. In Greening in the Red Zone (pp. 73-90). Springer, Dordrecht. https://doi.org/10.1007/978-90-481-9947-1_5

Olshansky, R. B. (2001). Land Use Planning for Seismic Safety: The Los Angeles County Experience, 1971-1994. Journal of the American Planning Association, 67(2), 173-185. https://doi.org/10.1080/01944360108976227

Omer, H., \& Alon, N. (1994). The continuity principle: A unified approach to disaster and trauma. American Journal of Community Psychology, 22(2), 273-287. https://doi.org/10.1007/BF02506866

Palermo, T. M. (2013). New Guidelines for Publishing Review Articles in JPP: Systematic Reviews and Topical Reviews. Journal of Pediatric Psychology, 38(1), 5-9. https://doi.org/10.1093/jpepsy/jss124

Park, S., Takeda, S., Kaga, H., \& Masuda, N. (2016). Study on Water and Greenery Networks in the "Green Master Plan and Master Plan for Parks and Open Spaces" of Kobe City. Urban and Regional Planning Review, 3, 203-221. https://doi.org/10.14398/urpr.3.203

Paton, D. (2003). Disaster preparedness: a social-cognitive perspective. Disaster Prevention and Management, 12(3), 210-216.

Petersen, M. D., Mueller, C. S., Moschetti, M. P., Hoover, S. M., Llenos, A. L., Ellsworth, W. L., ... Rukstales, K. S. (2016). 2016 one-year seismic hazard forecast for the Central and Eastern United States from induced and natural earthquakes (Report No. 2016-1035). Reston, VA. Retrieved from http://pubs.er.usgs.gov/publication/ofr20161035

Petticrew, M., \& Roberts, H. (2006). Systematic reviews in the social sciences: a practical guide. Malden, MA; Oxford: Blackwell Pub.

Pizzo, B., Di Salvo, G., Giuffré, M., \& Pellegrino, P. (2014). Earthquakes, public spaces and (the social construction of) environmental disasters. The role of public space for risk mitigation and urban redevelopment and the role of environmental disasters for reassessing the 'space of the Public'. IJPP Italian Journal of Planning Practice, 3(1), 441.

Prewitt Diaz, J. O., \& Dayal, A. (2008). Sense of Place: A Model for Community Based Psychosocial Support Programs. The Australasian Journal of Disaster and Trauma Studies, 2008(1). Retrieved from http://www.massey.ac.nz/ trauma/issues/20081/prewitt_diaz.htm

Pronyk, P. M., Harpham, T., Busza, J., Phetla, G., Morison, L. A., Hargreaves, J. R., Porter, J. D. (2008). Can social capital be intentionally generated? A randomized trial from rural South Africa. Social Science \& Medicine, 67(10), 1559-1570. https://doi.org/10.1016/j.socscimed.2008.07.022 
Public Architecture. (2013). ResilientSF: Presentation, "Golden Gate Park: A Sustainable Retrofit" by CMG Landscape Architecture. Retrieved from https://vimeo.com/79444385

Public Safety Canada. (2012). Your emergency preparedness guide. Retrieved from http://www.redcross.ca/crc/documents/3-1-2-1_-72-hour-guide.pdf

Pullin, A. S., \& Stewart, G. B. (2006). Guidelines for Systematic Review in Conservation and Environmental Management. Conservation Biology, 20(6), 1647-1656. https://doi.org/10.1111/j.1523-1739.2006.00485.x

Quarantelli, E. L. (1995). Patterns of sheltering and housing in US disasters. Disaster Prevention and Management: An International Journal, 4(3), 43-53. https://doi.org/10.1108/09653569510088069

Qui, Q., \& Gu, D. (2008). The Comparison of Domestic and Foreign Disaster Prevention Green Space and the Planning and Construction of Urban Disaster Shelter Green Space in China. Chinese Landscape Architecture. Retrieved from http://en.cnki.com.cn/Article_en/CJFDTOTAL-ZGYL200812021.htm

Reinoso, E., Jaimes, M. A., \& Torres, M. A. (2016). Evaluation of building code compliance in Mexico City: mid-rise dwellings. Building Research \& Information, 44(2), 202-213. https://doi.org/10.1080/09613218.2014.991622

Risler, E., Kintzle, S., \& Nackerud, L. (2015). Haiti and the Earthquake: Examining the Experience of Psychological Stress and Trauma. Research on Social Work Practice, 25(2), 251-256. https://doi.org/10.1177/1049731514530002

Robertson, A. H. (2015). In hot water: explaining Vancouver and San Francisco's responses to the impacts of climate change. University of British Columbia. Retrieved from http://hdl.handle.net/2429/54665

Rung, A. L., Broyles, S. T., Mowen, A. J., Gustat, J., \& Sothern, M. S. (2011). Escaping to and being active in neighbourhood parks: park use in a post-disaster setting. Disasters, 35(2), 383-403. https://doi.org/10.1111/j.1467-7717.2010.01217.x

Schencking, J. C. (2006). Catastrophe, Opportunism, Contestation: The Fractured Politics of Reconstructing Tokyo following the Great Kantô Earthquake of 1923. Modern Asian Studies, 40(4), 833-873. https://doi.org/10.1017/S0026749X06001934

Schencking, J. C. (2013). The great Kantō earthquake and the chimera of national reconstruction in Japan. New York: Columbia University Press.

Schultz, R., Wang, R., Gu, Y. J., Haug, K., \& Atkinson, G. (2017). A seismological overview of the induced earthquakes in the Duvernay play near Fox Creek, Alberta: Induced Seismicity Near Fox Creek. Journal of Geophysical Research: Solid Earth. https://doi.org/10.1002/2016JB013570 
Schwab, J. C. (Ed.). (2014). Planning for Post Disaster Recovery: Next Generation. American Planning Association. Retrieved from https://www.fema.gov/media-librarydata/1425503479190-22edb246b925ba41104b7d38eddc207f/APA_PAS_576.pdf

Shannon, K. (2015). Preemptive design opportunities to mitigate disasters. Journal of Landscape Architecture, 10(1), 4-5. https://doi.org/10.1080/18626033.2015.1011417

Shrestha, P. (n.d.). 83 open spaces to S.A.M, setting an Example in Nepal how parks and open spaces can strengthen communities' resilience toward disaster. Retrieved September 29, 2017, from http://nepal.iom.int/jupgrade/index.php/en/press-room/17-main/159-83open-spaces-to-s-a-m

Smith, K. (2013). Environmental hazards: assessing risk and reducing disaster (Sixth edition). London; New York: Routledge Taylor \& Francis Group.

Sorensen, A. (2002). The making of urban Japan: cities and planning from Edo to the twentyfirst century. London; New York: Routledge.

Sorensen, A., \& Funck, C. (Eds.). (2007). Living cities in Japan: citizens' movements, machizukuri and local environments. London ; New York: Routledge.

Statistics New Zealand. (2011). Estimating local populations after the 2010/11 Canterbury earthquakes. Wellington, N.Z.: Statistics New Zealand. Retrieved from http://www.stats.govt.nz/ /media/Statistics/browse-categories/population/estimatesprojections/estimating-pop-after-chch-quakes-paper/estimating-pop-after-chchearthquakes.pdf

Stefánsson, R. (2011). Advances in earthquake prediction: research and risk mitigation. Berlin: Springer.

Stein, S., \& Wysession, M. (2009). An Introduction to Seismology, Earthquakes, and Earth Structure. John Wiley \& Sons.

Steiner, F. (2014). Frontiers in urban ecological design and planning research. Landscape and Urban Planning, 125, 304-311. https://doi.org/10.1016/j.landurbplan.2014.01.023

Steinman, M., Lottenberg, C., Pavao, O. F., Kanamura, A., Aranha, L. F. C., Cenderoglo, M., \& Rizzo, L. V. (2012). Emergency response to the Haitian earthquake-As bad as it gets. Injury, 43(3), 386-387. https://doi.org/10.1016/j.injury.2010.06.018

Strauss, J. A., \& Allen, R. M. (2016). Benefits and Costs of Earthquake Early Warning. Seismological Research Letters, 87(3), 765-772. https://doi.org/10.1785/0220150149

Strusińska-Correia, A. (2017). Tsunami mitigation in Japan after the 2011 Tōhoku Tsunami. International Journal of Disaster Risk Reduction, 22, 397-411.

https://doi.org/10.1016/j.ijdrr.2017.02.001 
Su, Y., \& Liu, R. (2004). Disaster Mitigation Function of Disaster Prevention parks. Journal of Seismology. Retrieved from http://en.cnki.com.cn/Article_en/CJFDTOTALDZXK200402018.htm

Sudmeier, K., Jaboyedoff, M., \& Jaquet, S. (2013). Operationalizing "resilience" for disaster risk reduction in mountainous Nepal. Disaster Prevention and Management: An International Journal, 22(4), 366-377. https://doi.org/10.1108/DPM-02-2013-0028

Takaguchi, A. (2013, August 6). Tokyo parks gearing up to provide vital amenities in emergencies. The Japan Times Online. Retrieved from http://www.japantimes.co.jp/news/2013/08/06/national/tokyo-parks-gearing-up-toprovide-vital-amenities-in-emergencies/

The Sphere Project. (2011). Humanitarian Charter and minimum standards in humanitarian response. The Sphere Project. Retrieved from www.sphereproject.org

The Sphere Project. (n.d.). The Sphere Handbook | How to use this chapter. Retrieved November 16, 2017, from http://www.spherehandbook.org/en/how-to-use-this-chapter-1/

The Tokyo Rinkai Disaster Prevention Park. (n.d.-a). 1F Experience center. Retrieved November 3, 2017, from http://www.tokyorinkai-koen.jp/en/1f/

The Tokyo Rinkai Disaster Prevention Park. (n.d.-b). 2F Learning center. Retrieved November 3, 2017, from http://www.tokyorinkai-koen.jp/en/2f/

The Tokyo Rinkai Disaster Prevention Park. (n.d.-c). History of Development Operations. Retrieved December 16, 2017, from http://www.ktr.mlit.go.jp/showa/tokyorinkai/english/about/index.htm

The University of Tokyo. (n.d.). The World's Most Active Earthquake Zone Is the Closest Place on Earth to Unraveling World-shaking Geophysical Mysteries. Retrieved June 23, 2017, from http://www.u-tokyo.ac.jp/en/whyutokyo/wj_001.html

Thoms, E. E., Haeussler, P. J., Anderson, R. D., \& McGimsey, R. G. (2014). 1964 Great Alaska Earthquake-A photographic tour of Anchorage, Alaska (Open-File Report No. 20141086) (p. 48). U.S. Geological Survey. Retrieved from https://pubs.usgs.gov/of/2014/1086/pdf/ofr2014-1086.pdf

Tokyo Bureau of Construction. (n.d.). Enjoy and Learn About Disaster Prevention: Tokyo Rinkai Disaster Prevention Park. Retrieved from http://www.kensetsu.metro.tokyo.jp/content/000007607.pdf

Tokyo Metropolitan Government. (n.d.). Disaster Preparedness Tokyo. Retrieved from http://www.metro.tokyo.jp/ENGLISH/GUIDE/BOSAl/index.htm

Torgerson, C. (2003). Systematic reviews. London; New York: Continuum. 
Tumini, I., Villagra-Islas, P., \& Herrmann-Lunecke, G. (2017). Evaluating reconstruction effects on urban resilience: a comparison between two Chilean tsunami-prone cities. Natural Hazards, 85(3), 1363-1392. https://doi.org/10.1007/s11069-016-2630-4

Turer Baskaya, F. A. (2012). Understanding the Power of Landscape in Building a Disaster Resilient City from Istanbul. In The Power of Landscape. Warsaw.

Turer Baskaya, F. A. (2015). Disaster sensitive landscape planning for the coastal megacity of Istanbul. Journal of Coastal Conservation, 19(5), 729-742. https://doi.org/10.1007/s11852-014-0365-5

Tyrväinen, L., Ojala, A., Korpela, K., Lanki, T., Tsunetsugu, Y., \& Kagawa, T. (2014). The influence of urban green environments on stress relief measures: A field experiment. Journal of Environmental Psychology, 38, 1-9. https://doi.org/10.1016/j.jenvp.2013.12.005

Uchida, M., Yuzawa, A., \& Tsukada, S. (2015). A Study on Benefit Evaluation of disaster Prevention in Large Scale Urban Park by Stated Preference Model. Journal of the City Planning Institute of Japan, 50(3), 409-415. https://doi.org/10.11361/journalcpij.50.409

UN. (2016, March 10). As "most disaster-prone region," Asia-Pacific needs risk-sensitive development, UN reports. Retrieved November 29, 2017, from http://www.un.org/apps/news/story.asp?NewsID=53407\#.Wh47PLYZOV4

UNISDR. (2009). 2009 UNISDR Terminology on Disaster Risk Reduction. UNISDR. Retrieved from http://www.unisdr.org/files/7817_UNISDRTerminologyEnglish.pdf

UNISDR. (2015, November 12). Disaster Risk. Retrieved October 3, 2017, from http://www.preventionweb.net/risk/disaster-risk

UNISDR. (2016, April 20). How can we make earthquakes less deadly? Retrieved April 7, 2017, from https://www.unisdr.org/archive/48592

UNISDR. (2017, February 2). Terminology. Retrieved October 6, 2017, from https://www.unisdr.org/we/inform/terminology\#letter-r

United Nations Office for the Coordination of Humanitarian Affairs. (2012, December 11). Floods deaths down but economic losses significant - World | ReliefWeb. Retrieved December 18, 2017, from https://reliefweb.int/report/world/floods-deaths-down-economic-lossessignificant

USGS. (2006, September 18). About Liquefaction. Retrieved September 14, 2017, from https://geomaps.wr.usgs.gov/sfgeo/liquefaction/aboutliq.html

USGS. (n.d.-a). Earthquake Early Warning. Retrieved October 3, 2017, from https://earthquake.usgs.gov/research/earlywarning/overview.php 
USGS. (n.d.-b). What does an earthquake feel like? Retrieved November 27, 2017, from https://www.usgs.gov/faqs/what-does-earthquake-feel?qt-news_science_products=7\#qtnews_science_products

Usman, M. (2016). A study on the enhancing earthquake frequency in northern Pakistan: is the climate change responsible? Natural Hazards, 82(2), 921-931.

https://doi.org/10.1007/s11069-016-2226-z

Vallance, S. (2011). Early disaster recovery: a guide for communities. Australasian Journal of Disaster and Trauma Studies, 2011(2), 19-25.

van den Berg, A. E., Maas, J., Verheij, R. A., \& Groenewegen, P. P. (2010). Green space as a buffer between stressful life events and health. Social Science \& Medicine, 70(8), 12031210. https://doi.org/10.1016/j.socscimed.2010.01.002

Villagra, P., Rojas, C., Ohno, R., Xue, M., \& Gómez, K. (2014). A GIS-base exploration of the relationships between open space systems and urban form for the adaptive capacity of cities after an earthquake: The cases of two Chilean cities. Applied Geography, 48, 6478. https://doi.org/10.1016/j.apgeog.2014.01.010

Villagra-Islas, P., \& Alves, S. (2016). Open space and their attributes, uses and restorative qualities in an earthquake emergency scenario: The case of Concepción, Chile. Urban Forestry \& Urban Greening, 19, 56-67. https://doi.org/10.1016/j.ufug.2016.06.017

Villagra-Islas, P., \& Dobbie, M. (2014). Design Aspects of Urban Wetlands in an EarthquakeProne Environment. Journal of Urban Design, 19(5), 660-681. https://doi.org/10.1080/13574809.2014.943707

Walker, B. H., \& Salt, D. (2006). Resilience Thinking: Sustaining Ecosystems and People in a Changing World. Washington, DC: Island Press. Retrieved from http://search.ebscohost.com.subzero.lib.uoguelph.ca/login.aspx?direct=true\&db=nlebk\& AN=203979\&site=ehost-live\&scope=site

Wang, C., Pan, J., \& Li, S. (2014). Disaster prevention system planning of Zhaxike Wetland Park in Yushu, Qinghai. Landscape Architecture Frontiers, 2(4), 96+.

Wang, Z. (2008). A preliminary report on the Great Wenchuan Earthquake. Earthquake Engineering and Engineering Vibration, 7(2), 225-234. https://doi.org/10.1007/s11803008-0856-1

Weisenfeld, G. S. (2012). Imaging disaster: Tokyo and the visual culture of Japan's Great Earthquake of 1923. Berkeley: University of California Press.

Wenzel, F., Bendimerad, F., \& Sinha, R. (2007). Megacities - megarisks. Natural Hazards, 42(3), 481-491. https://doi.org/10.1007/s11069-006-9073-2 
Wesener, A. (2015). Temporary urbanism and urban sustainability after a natural disaster: transitional community-initiated open spaces in Christchurch, New Zealand. Journal of Urbanism: International Research on Placemaking and Urban Sustainability, 8(4), 406422. https://doi.org/10.1080/17549175.2015.1061040

World Bank, \& United Nations (Eds.). (2010). Natural hazards, unnatural disasters: the economics of effective prevention. Washington, D.C: World Bank.

Wu, Z. D., \& Liu, H. Y. (2013). Application of GIS in Urban Disaster Prevention Park Planning. Applied Mechanics and Materials, 357-360, 1822-1827. https://doi.org/10.4028/www.scientific.net/AMM.357-360.1822

$\mathrm{Xu}, \mathrm{H}$. (2013). Modern landscape architecture: proceedings of the 6th WSEAS international conference on landscape architecture - Article Title: The Evolution and Characteristics of the Green Space System Planning in Japan. (J. B. Burley, Ed.). Nanjing, China,.

Yao, F., Lusi, Z., Mingqi, S., \& Qi, M. (2015). Discussion on the construction of disaster prevention green infrastructure network planning. In Advances in Engineering Research (Vol. 47). Xi'an, China: Atlantis Press.

Zhou, Y., Shen, S., \& Tang, L. (2012). Investigation of Urban Disaster-Prevention Green Space - Taking Changsha City for Example. Journal of Green Science and Technology. Retrieved from http://en.cnki.com.cn/Article_en/CJFDTOTAL-LVKJ201206103.htm

Zhu, C., Wang, Y., Ren, W., Luo, I., Yin, Y., Xie, W., \& Liu, W. (2016). The Planning of Green Spaces to Prevent and Avoid Urban Disasters in Dujiangyan. International Journal of Simulation Systems, Science \& Technology, 17(46). Retrieved from http://ijssst.info/Vol17/No-46/paper27.pdf 


\section{APPENDIX A | Induced Seismicity}

Melting glaciers associated with our increasingly variable climate are changing the load across fault lines, releasing pressure resulting in isostatic, or post-glacial rebound. This change in pressure can increase earthquake frequency (Usman, 2016). More rapid and sporadic glacial movement can also produce enough force that the seismic waves it generates can be detected by global seismometers (Ekstrom, 2006).

Increased erosion due to changes in the intensity of rainfall may also cause a shift in load across a fault (Usman, 2016). Research is also emerging which indicates that groundwater depletion is increasing seismic risk. Amos et al. (2014), for instance, have linked ground water depletion in Sierra Nevada, California, to the long-term destabilization of the San Andreas Fault.

Unlike post-glacial rebound and ground water depletion, hydraulic fracturing increases the pressure and load on an existing fault, stimulating tremors (Schultz et al., 2017). In 2015, The U.S. Geological Survey released a report, which for the first time forecasted both natural and induced earthquakes in the Central and Eastern United States. In central Alberta, Canada a relatively seismically inactive province, 25 earthquakes (ranging from magnitude 2.5 to 3.5 ), were recorded from 2013 to 2017 . The increase in seismic activity was linked to nearby hydraulic fracturing (Schultz et al., 2017).

Because political and economic decisions can increase or halt activities that contribute to induced seismicity, there has been reluctance from building-code committees to include data on induced seismic events (Petersen et al., 2016). Areas with naturally low seismic activity from earthquake hazards are ill prepared to deal with this changing hazardscape. 


\section{APPENDIX B | Prediction \& Early Warning}

\section{Prediction}

At present there is insufficient data on many faults to establish long-term patterns of recurrence (Stein \& Wysession, 2009). Moreover, despite extensive hazard maps of known faults, new seismic events continue to reveal hidden faults. For example, both the 2010 Darfield earthquake and 2011 M 6.2 aftershock that caused significant damage to Christchurch, New Zealand, occurred on previously unmapped faults (Elwood, 2013; Kaiser et al., 2012).

\section{Early Warning}

Because primary waves (P-waves) generated by the fault rupture travel faster than secondary waves (S-waves), which cause the destructive shaking, it is possible to trigger an early warning before the S-waves arrival. Depending on a person's location from the earthquake epicenter, this early warning may provide seconds to over a minutes notice before the S-waves hit(Allen, Gasparini, Kamigaichi, \& Bose, 2009; USGS, n.d.-a). Mobile phones, radios and televisions broadcast alerts, critical systems can be automatically shut down, and emergency services are notified and prepared for response.

Nevertheless, even with extensive implementation of early warning systems, there is the issue of human reaction to warnings. Underestimating the seriousness of the warning, inaction or delayed action can compromise the effectiveness of the early warning (e.g. Omer \& Alon, 1994). In addition, although vulnerable populations have the greatest need for early warning, vulnerability may in fact impede access to early warnings (Masterson et al., 2014). 


\section{APPENDIX C | Secondary Disasters}

\section{Liquefaction}

When subjected to shaking during an earthquake, grains in saturated soils separate, causing the soil to act as a liquid, erupting up from the ground and compromising structures (USGS, 2006). Reclaimed land near bodies of water are particularly vulnerable to liquefaction. In Christchurch, New Zealand, liquefaction after the 2010 earthquake and 2011 aftershock caused sever damage to structures located near the estuary and Avon river, with losses totalling over 10 billion dollars (Cubrinovski et al., 2011; Daniell et al., 2017; Kaiser et al., 2012).

\section{Landslides \& Flooding}

In mountainous regions or areas with steep slopes, earthquakes can trigger landslides. Ground shaking destabilizes slopes, causing an avalanche of soil, rock or snow. If river systems are blocked by debris from landslides, flooding or "quake lakes" (Daniell et al., 2017, p. 5) may occur. Structural damage to dams or reservoirs from ground shaking can also cause flooding (Daniell et al., 2017).

\section{Fire}

Fire has historically been the most damaging secondary effect following an earthquake. Countries with primarily timber frame building stock are particularly vulnerable to damage from fire. Although fire accounts for the highest economic losses from secondary effects, with better management, construction materials and building techniques, losses due to fires are dropping (Daniell et al., 2017).

\section{Tsunami}

Although events such as volcanic eruptions, landslides and meteorite impacts can trigger tsunamis, earthquakes are the most common cause (Australian Government, 2014; Smith, 2013). Movement of offshore faults can displace large amounts of water which increase in amplitude the closer the wave moves to the coast, ultimately causing a series of destructive waves (Daniell et al., 2017). Unlike earthquakes, it is possible to predict the arrival of a tsunami, providing critical lead-time for low-lying coastal areas to evacuate (Smith, 2013). 


\section{APPENDIX D | Building Codes \& Compliance}

High-density areas, such as a central business district are particularly vulnerable during an earthquake. Although areas with low-rise structures and lower density tend to fare better, they can be equally susceptible to building collapse if construction measures are not adequate. In 2008, the Wenchuan Earthquake in China's Sichuan Province, was estimated to have destroyed approximately 1.5 million homes and damaged 6 million more, leaving China with the largest population of homeless in history to date (Daniell, 2013). The majority of homes in the region had little or no earthquake resistance (Wang, 2008).

In Haiti, the 2010, 7.0 magnitude earthquake claimed 230,000 lives (Bellegarde-Smith, 2011), most due to building collapse. Yet, the same magnitude earthquake in Christchurch, New Zealand, just months after the Haitian disaster had no fatalities. This sobering contrast is a reminder "...that poor building practices are largely to blame for turning moderate earthquakes into major disasters" (Ambraseys \& Bilham, 2011, p. 153). Having building codes, and enforcing compliance of those codes, is a critical component of earthquake mitigation. Had this been the case in locations like Haiti and China, mass casualties from building collapse could have been largely avoided.

Even with codes in place, monitoring, evaluation and compliance remains an issue. In Mexico City, for example, the responsibility for verification of buildings meeting performance standards is no longer under the purview of local government; instead, it is left to professionals in the construction industry, who are often under-qualified and face no legal action if future losses occur as a result of structural damage (Reinoso, Jaimes, \& Torres, 2016). In addition, there is currently no official means of assessing a building's seismic risk and evaluations vary with each inspector (Reinoso et al., 2016).

However, even in countries with better industry self-regulation, review boards and repercussions for negligence, issues still remain. Christchurch, which had faired so well in the 2010 earthquake, experienced an aftershock five months after the initial earthquake that brought in to question the safety of the city's structures. The 2011, magnitude 6.2 aftershock claimed the lives of 185 people. The largest loss of life happened as a result of a single building collapse. The collapse of the Canterbury Television building, a six-story structure located in the downtown core, killed 115 people. Investigations into the collapse ultimately found that the building failed to meet relevant standards when it was constructed in 1986 (Howard, 2012). 
Many cities are also dealing with aging building stock constructed before the introduction of seismic codes, or buildings that were constructed to codes that are no longer current. Canadian seismic building codes were first introduced in 1941, since then there have been 13 updated editions. In British Columbia, Canada's most seismically active province (Government of Canada, 2015), there are no bylaws that require building owners to upgrade to meet the new provisions in the code (Hoekstra, 2016). 


\section{APPENDIX E | Disaster Prevention Park Synonyms}

\begin{tabular}{|l|l|}
\hline China & (Li \& Xia, 2007; Wu \& Liu, 2013) \\
\hline Urban Disaster Prevention Park & (Hong, Hu, Chen, Wang, \& Xiao, \\
\hline Urban Disaster-Prevention Green Space & 2010; Zhou, Shen, \& Tang, 2012) \\
\hline Urban Disaster Prevention Land & (Jia et al., 2008) \\
\hline Urban Disaster Relief Green Space & (Li, 2014) \\
\hline Urban Calamity Prevention Green Space & (Guo \& Liu, 2006) \\
\hline Disaster Reduction Park & (Fei \& Yu, 2010) \\
\hline Disaster Prevention Green Field & (Jia et al., 2008) \\
\hline Disaster Prevention Green Space & (Li, 2014; Zhou et al., 2012; Yao et al., \\
\hline Disaster-Prevention Urban Green Space & 2015) \\
\hline Disaster-Prevention Urban Parks & (Li, 2010) \\
\hline Disaster Prevention Parks & (Li, 2014) \\
\hline Disaster-Proof Parks & (Li \& Xia, 2007; Su \& Liu, 2004; \\
\hline Disaster Prevention Squares & Wang, Pan, \& Li, 2014) \\
\hline Urban Disaster Prevention And Avoidance & (Lu, Xue, \& Zhao, 2006) \\
Green Space & (Liu et al., 2014) \\
\hline Disaster Relief Landscapes & (Zhu et al., 2016) \\
\hline Green Spaces For Disaster Prevention And & (Li, 2014) \\
Mitigation & (Hong \& Guo, 2017) \\
\hline Japan & \\
\hline Refuge Parks & (Mckean, 2014) \\
\hline Disaster-Survival Parks & (Mckean, 2014) \\
\hline Disaster Prevention Parks & (Uchida, Yuzawa, \& Tsukada, 2015) \\
\hline Disaster Prevention Park System & (Xu, 2013) \\
\hline Disaster Refuge Park System & (Masuda, 2014) \\
\hline Disaster-Prevention Base (Bôsai Kyokuten) & (Flüchter, 2003; Park et al., 2016; \\
\hline Misaster Relief Parks & Matsuda, 1990) \\
\hline Disaster Refuge Parks & (Masuda, 2014) \\
\hline Taiwan & (Huang \& Chu, 2016) \\
\hline Disaster Prevention Park & (Villagra-lslas \& Dobbie, 2014) \\
\hline Chile & (Gülgün, Yazici, Dursun, \& Türkyılmaz \\
\hline Urban Spaces For Disaster Recovery & Tahta, 2016; Celik \& Erduran, 2011) \\
\hline Turkey & \\
\hline Earthquake Park & \\
\hline &
\end{tabular}

